\title{
$m 96050284$
}

COMMERCIAL DEMONSTRATION OF THE NOXSO

$\mathrm{SO}_{2} / \mathrm{NO}_{\mathrm{x}}$ REMOVAL FLUE GAS CLEANUP SYSTEM

Contract No. DE-FC22-91PC90549

Quarterly Technical Progress Report No. 12

Submitted to

U.S. Department of Energy

Pittsburgh Energy Technology Center

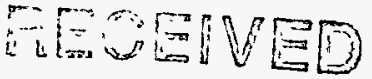

AUG 261986

OSTI

December 1, 1993 through February 28, 1994

Project Definition Phase

U.S. DOE Patent Clearance Is Not Required Prior to the Publication of this Document

\section{DISCLAIMER}

This report was prepared as an account of work sponsored by an agency of the United States Government. Neither the United States Government nor any agency thereof, nor any of their employees, makes any warranty, express or implied, or assumes any legal liability or responsibility for the accuracy, completeness, or usefulness of any information, apparatus, product, or process disclosed, or represents that its use would not infringe privately owned rights. Reference herein to any specific commercial product, process, or service by trade name, trademark, manufacturer, or otherwise does not necessarily constitute or imply its endorsement, recommendation, or favoring by the United States Government or any agency thereof. The views

Prepared by and opinions of authors expressed herein do not necessarily state or reflect those of the United States Government or any agency thereof.

Morrison Knudsen Corporation

Ferguson Division

1500 West 3rd Street

Cleveland, Ohio 44113-1406 
DISCLAIMER

Portions of this document may be illegible in electronic image products. Images are produced from the best available original document. 
Table of Contents

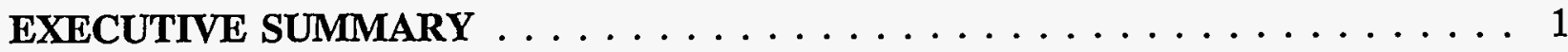

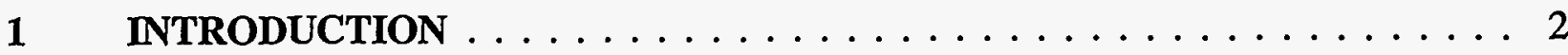

2 PROJECT DESCRIPTION $\ldots \ldots \ldots \ldots \ldots \ldots \ldots$

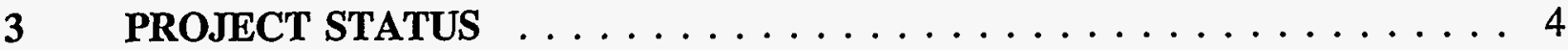

3.1 Project Management . . . . . . . . . . . . . . . . . 5

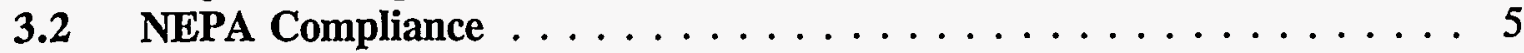

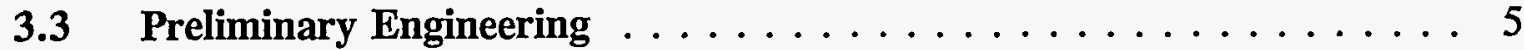

3.3.1 General Arrangement with Self Supporting Vessels . . . . . . . 5

3.3.2 Process Vessel Design ..................... 6

3.3.3 Plant Availability . . . . . . . . . . . . . . . . . . 10

3.3.3.1 Pilot Plant Gross Availability . . . . . . . . . 10

3.3.3.2 Pilot Plant Net Availability . . . . . . . . . . . . . 12

3.3.3.3 Failure Analysis . . . . . . . . . . . . . . . . . 14

3.3.3.4 Projected Commercial Plant Availability . . . . . . . . 16

3.3.4 Equipment Sparing . . . . . . . . . . . . . . 16

3.3.4.1 Rotating Equipment . . . . . . . . . . . 17

3.3.4.2 Control Valves . . . . . . . . . . . . . 18

3.3.4.3 Sorbent Transport Systems $\ldots \ldots \ldots \ldots \ldots$

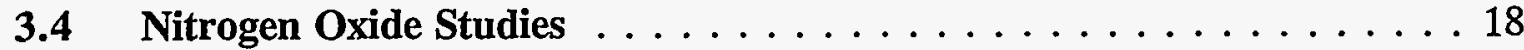

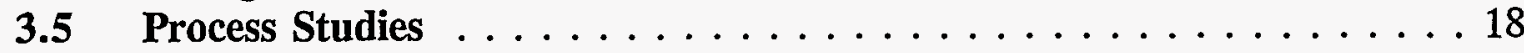

3.5.1 Sorbent Heater/Cooler Energy Balance . . . . . . . . . . . 18

3.5 .2 Adsorber Model . . . . . . . . . . . . . . . . . . . . . . . . . . . . . . . . . . . . . . .

3.5.3 Process Simulation . . . . . . . . . . . . . . . 37

3.5 .4 Process Economics . . . . . . . . . . . . . . . 37

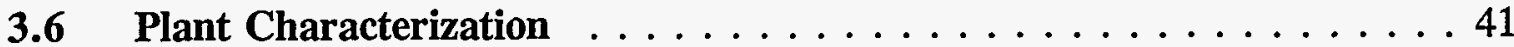

3.7 Site Survey/Geotechnical Investigation $\ldots \ldots \ldots \ldots \ldots \ldots$

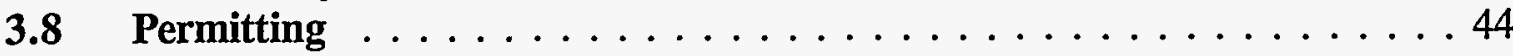

4 PLANS FOR NEXT QUARTER $\ldots \ldots \ldots \ldots \ldots \ldots \ldots$

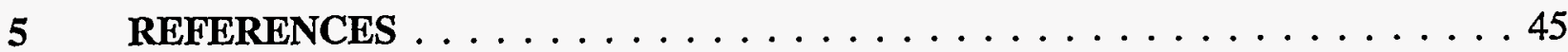

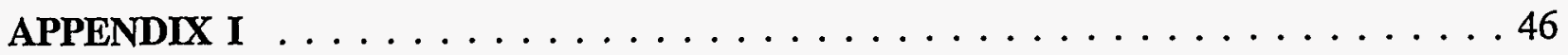




\section{List of Figures}

Figure 1-1 NOXSO Process Diagram . . . . . . . . . . . . . . . . 3

Figure 3-1 General Arrangement with Structural Steel Supporting Vessels . . . . . . . 7

Figure 3-2 General Arrangement Self Supporting Vessels . . . . . . . . . . . 8

Figure 3-3 Energy Balance Water Effect - Sorbent Heater . . . . . . . . . . . . 21

Figure 3-4 Energy Balance Water Effect - Sorbent Cooler . . . . . . . . . . . . . 22

Figure 3-5 Fixed Bed Adsorption @ 120C . . . . . . . . . . . . . . 24

Figure 3-6 Fixed Bed Adsorption @ 180C . . . . . . . . . . . . . . . . . 25

Figure 3-7 Comparison of $\mathrm{SO}_{2}$ Removal Efficiencies for POC Fluid-bed Adsorber . . 28

Figure 3-8 Comparison of $\mathrm{NO}_{x}$ Removal Efficiencies for POC Fluid-bed Adsorber . . . 29

Figure 3-9 Inlet $\mathrm{NO}_{\mathrm{x}}$ Concentration Effect $\ldots \ldots \ldots \ldots \ldots \ldots \ldots \ldots$

Figure 3-10 Inlet $\mathrm{SO}_{2}$ Concentration Effect $\ldots \ldots \ldots \ldots \ldots \ldots \ldots \ldots \ldots \ldots \ldots$

Figure $3-11$ Superficial Gas Velocity Effect $\ldots \ldots \ldots \ldots \ldots \ldots \ldots \ldots \ldots \ldots \ldots$

Figure 3-12 Adsorber Temperature Effect . . . . . . . . . . . . . . . 33

Figure $3-13$ Sorbent Residence Time Effect . . . . . . . . . . . . . . . 34

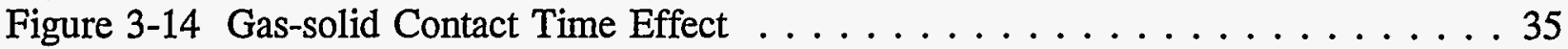

Figure $3-15$ POC Adsorber $\mathrm{NO}$ and $\mathrm{NO}_{\mathrm{x}}$ Emission $\ldots \ldots \ldots \ldots \ldots \ldots \ldots \ldots \ldots \ldots$

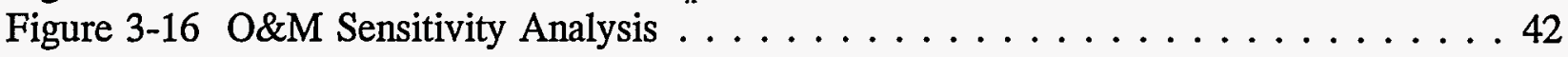




\section{List of Tables}

Table 3-1. Pilot Plant Outage Events . . . . . . . . . . . . . . . 11

Table 3-2. Pilot Plant Gross Availability . . . . . . . . . . . . . . 12

Table 3-3. Pilot Plant Net Availability . . . . . . . . . . . . . . . . 13

Table 3-4. Design Changes Based on Pilot Plant Performance . . . . . . . . . . . 14

Table 3-5. Projected NOXSO Commercial Plant Availability . . . . . . . . . 16

Table 3-6. Equipment Sparing . . . . . . . . . . . . . . . . . 17

Table 3-7. Sorbent Capacities and Rate Constants for Sorption . . . . . . . . . 26

Table 3-8. Design Criteria for Economic Analysis . . . . . . . . . . . . . . 38

Table 3-9. NOXSO Process Economic Analysis(1) . . . . . . . . . . . . . 39

Table 3-10. Raw Material and Utility Consumption . . . . . . . . . . . 43 


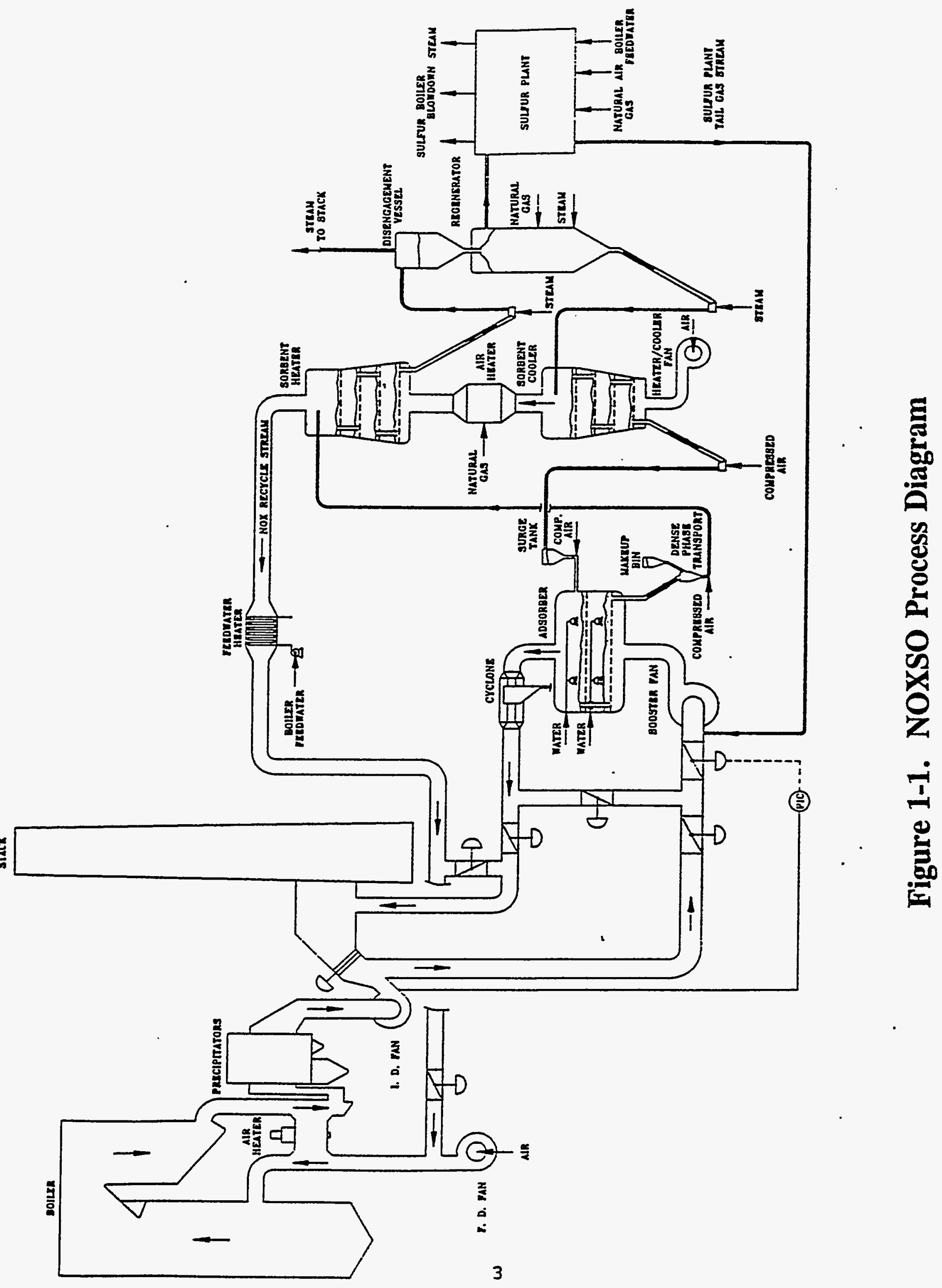


High temperature sorbent exiting the regenerator is conveyed to the multi-stage fluidized bed sorbent cooler. The sorbent flows counter to the ambient air which cools the sorbent. Regenerated sorbent exits the cooler at $295^{\circ} \mathrm{F}$. It is then conveyed to the adsorber, completing the sorbent cycle.

Ambient air which is forced through the sorbent cooler by the heater-cooler fan exits the sorbent cooler at approximately $850^{\circ} \mathrm{F}$. This preheated air then enters the air heater where it is heated to approximately $1325^{\circ} \mathrm{F}$ so it is capable of heating the sorbent exiting the sorbent heater to $1150^{\circ} \mathrm{F}$.

\section{PROJECT DESCRIPTION}

The objective of the NOXSO Demonstration Project is to design, construct, and operate a commercial scale flue gas treatment system utilizing the NOXSO process. The effectiveness of the process will be demonstrated by achieving significant reductions in emissions of sulfur and nitrogen oxides. In addition, sufficient operating data will be obtained to confirm the process economics and provide a basis to guarantee performance on a commercial scale.

\section{PROJECT STATUS}

The project is currently in the project definition and preliminary design phase. This phase of the project was included to allow completion of the pilot plant testing before a significant design effort was expended. The NOXSO pilot plant test program was completed on July 30,1993 . Performance at the pilot plant exceeded the initial expectations for pollutant removal efficiency, sorbent attrition, and electrical power and natural gas consumption. Pollutant removal efficiency was enhanced significantly by the addition of the second bed in the adsorber and in bed water sprays to lower the adsorber temperature.

Data from the pilot plant has been incorporated into a fully integrated computer simulation which efficiently performs heat and material balances for the combined NOXSO plant, power plant, and sulfur plant system. The computer program also calculates sizes and capacities for the major process equipment. This computer simulation is used to evaluate process alternatives to determine their impact on process economics.

A preliminary process flow diagram and associated heat and material balances have been prepared for a commercial size plant. This flow diagram incorporates lessons learned from the pilot plant test program as well as results of laboratory process studies, theoretical process studies, and the computer simulation. Preliminary piping and instrumentation diagrams have been prepared for a commercial size plant based on the pilot plant experience and the preliminary process flow diagram. 
Figure 3-1. General Arrangement with Structural Steel Supported Vessels

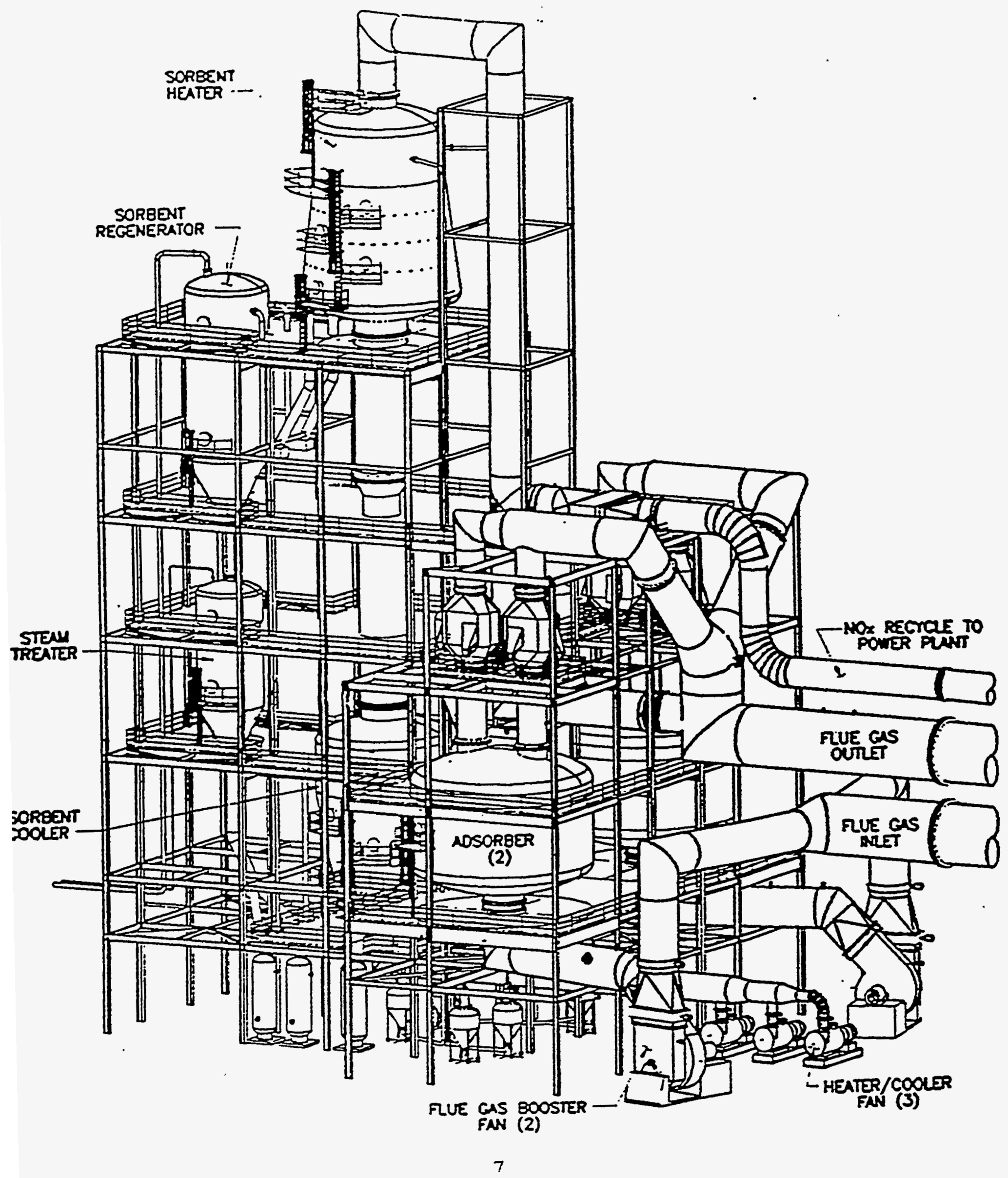


Figure 3-2. General Arrangement with Self Supporting Vessels

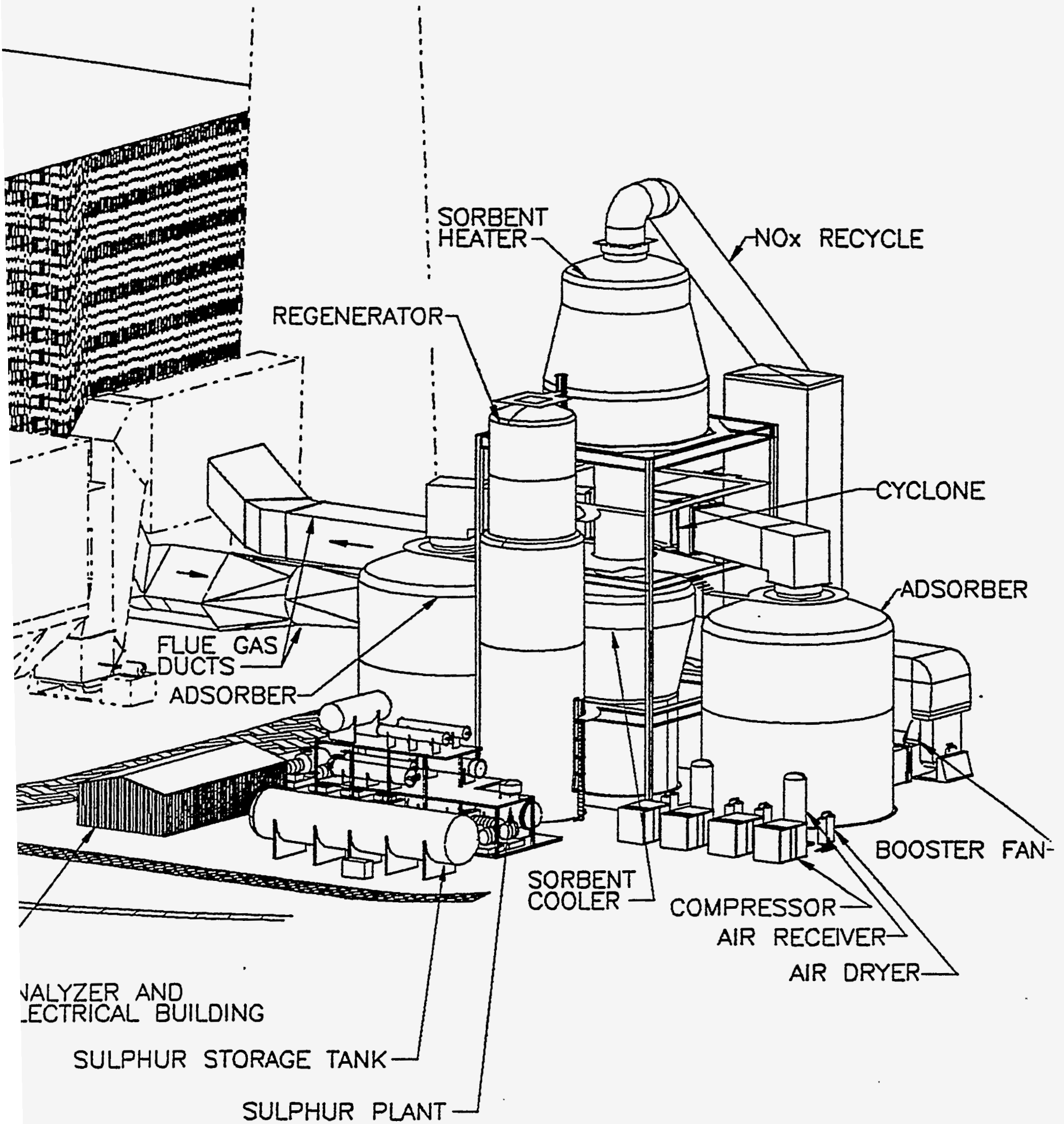


Positive internal design pressure of the adsorber, cooler and heater is based on the dead head pressure of the respective fans plus a margin to prevent lifting of the safety relief valves should the fans be dead headed. Negative internal (or external) design pressure is based on the maximum draft that the stack is capable of pulling, plus a margin to prevent opening the vacuum breakers.

Positive internal design pressure of the regenerator and steam disengagement vessel is set by the dead head pressure of the heater/cooler fan, the hydrostatic head exerted by the sorbent and a margin to prevent opening the safety relief device should this upset occur.

Design temperature of the adsorber is set by the power plant combustion air pre-heater discharge temperature at a reduced boiler load with full $\mathrm{NO}_{\mathrm{x}}$ recycle flow. Added to this is the temperature rise across the booster fans and a safety margin bringing the typical value to $400^{\circ} \mathrm{F}$. The allowable stress of carbon steels does not begin to decrease until $600^{\circ} \mathrm{F}$ is exceeded so the adsorber design temperature is not critical since it will never approach this value.

The design temperature of the sorbent heater and sorbent cooler is set by the sorbent regeneration temperature of $1150^{\circ} \mathrm{F}$. To reach this sorbent temperature requires a sorbent heater gas inlet temperature to the sorbent heater of $1325^{\circ} \mathrm{F}$. To provide a margin of safety, the sorbent heater design temperature is set at $1400^{\circ} \mathrm{F}$. During normal operating conditions sorbent enters the sorbent cooler at $990^{\circ} \mathrm{F}$. To provide a margin of safety, the sorbent cooler design temperature is set at $1050^{\circ} \mathrm{F}$.

The regenerator and steam treater are refractory lined. The lining is both corrosion resistant and insulating, allowing the pressure boundary to be carbon steel. The lining is designed to provide a shell temperature of $130^{\circ} \mathrm{F}$. The design temperature of the pressure boundaries of these vessels is $200^{\circ} \mathrm{F}$.

The self supporting vessels require skirts to support them. The attachment point for the skirt is selected to minimize bending movements in the vessel wall and supporting skirt, resulting in a predominantly compressive load. The skirts are designed using the same code rules used for the vessels under the compressive load of their own weight. In contrasts, hanging vessels of this weight using mounting lugs exerts large bending moments on the vessel wall. To keep vessel wall stresses within allowable limits the walls must be thickened to accommodate the additional loading. To distribute the loads exerted by the lugs, circumferential rings are attached to the lugs and vessel wall. Consequently, the additional material required for the supporting skirt is substantially off-set by elimination of the mounting lugs, thickened vessel walls, and circumferential rings.

Specifically, to minimize high local stress concentration the skirt attachment point and head type are important. The ASME code suggests the use of 2:1 ellipsoidal heads with the mean diameter of the skirt coinciding with the mean diameter of the vessel. This is most important in the sorbent heater where local stress concentrations can lead to excessive creep and premature failure of the vessel. 
The process vessel code calculations are in a spreadsheet format for flexibility in making changes. Appendix I of this report contains the adsorber calculations.

\subsubsection{Plant Availability}

To assure that lessons learned at the NOXSO pilot plant are incorporated in the commercial plant design, a detailed analysis of pilot plant availability was conducted. Additionally, using this study as a basis, availability of a commercial plant incorporating the lessons learned is estimated at greater than $99 \%$.

The time period of pilot plant operation used for the analysis was April to December 1992. Most of the parametric testing took place during this time period and extra efforts were made to attain consistent, quality performance from the plant.

During this period, there were 37 instances in which the plant went off of flue gas. These shutoffs, or outages, ranged in time from 40 minutes to three weeks. Often just the flue gas needed to be shut off to take the necessary corrective action, other times the entire plant was shut down. After evaluation of the flue gas outages, each incident was categorized based on the cause of the occurrence. Figure 3-2 shows the reason for each outage, the cause of the event, and the number of times each event occurred during this time period.

\subsubsection{Pilot Plant Gross Availability}

The NOXSO pilot plant gross availability was $75 \%$. The gross availability, as calculated in Figure 3-2 is the time spent processing flue gas divided by the time that flue gas was available for processing. The time that flue gas was available for processing is dependant on the power plant operations. The power plant unavailability was responsible for those events in Table 3-1 classified as "power plant". This time appears as host flue gas interruptions in Table 3-2.

The events and times listed under "less all outages" in Table 3-2 represent the remainder of the shutdowns listed in Table 3-1. For instance, "heater modification shutdowns" in Table 3-2 refers to "planned shutdowns" in Table 3-1. Also, "system checks and Mech./Elec. outages and repairs" refers to all of the mechanical and electrical failures listed in Table 3-1. They are listed in Table 3-2 this way to reflect the fact that while it was a mechanical or electrical failure which caused the outage, much of the corresponding downtime was spent making plant modifications, vessel inspections, instrument calibrations, etc. that were not related to the original cause of the outage. The distinction is made here because it will have a considerable effect on the pilot plant net and projected commercial plant availabilities. 
Table 3-1. Pilot Plant Outage Events

\begin{tabular}{|l|l|c|}
\hline Reason For Outage & Cause of Problem or Event & No. \\
\hline Calibration drift & $\begin{array}{l}\text { MAC capacitance level probes needed } \\
\text { recalibration }\end{array}$ & 3 \\
\hline Mechanical failure & $\begin{array}{l}\text { Sorbent heater grid warpage, grid hole } \\
\text { pluggage \& blown rupture disk }\end{array}$ & 2 \\
\hline Mechanical failure & Regenerator control valve improperly seated & 2 \\
\hline Mechanical failure & Hole in incinerator off-gas duct at steam inlet & 2 \\
\hline Electrical failure & $\begin{array}{l}\text { MAC level probe failed due to disconnected } \\
\text { wire }\end{array}$ & 1 \\
\hline Mechanical failure & Top J-valve fluidizing grid plugged & 1 \\
\hline Mechanical failure & Flue gas fan bearings needed lubrication & 1 \\
\hline Mechanical failure & Acid line clog caused adsorber grid pluggage & 1 \\
\hline Electrical failure* & Power outage & 1 \\
\hline Plant modification & DCS reconfiguration & 1 \\
\hline Plant modification & $\begin{array}{l}\text { Incinerator damper and control loop } \\
\text { modifications }\end{array}$ & 1 \\
\hline Planned shutdown & $\begin{array}{l}\text { Sorbent heater grid warpage and grid hole } \\
\text { pluggage }\end{array}$ & 2 \\
\hline Operating conditions & Oversulfation of sorbent & 1 \\
\hline Operating conditions & $\begin{array}{l}\text { Adsorber grid pluggage caused by acid } \\
\text { carryover }\end{array}$ & 1 \\
\hline Operator error & Incinerator malfunction & 7 \\
\hline Operator error & Regenerator level gauge accidently shut off & 1 \\
\hline Calibration & MAC calibration & 2 \\
\hline Power plant & Power plant off line & 1 \\
\hline Holiday & Thanksgiving \& Christmas & 2 \\
\hline Project review & Process shutdown & 2 \\
\hline & & 2 \\
\hline
\end{tabular}

* Relevant failures for projected commercial availability calculations of Table 3-2. 
Table 3-1. Pilot Plant Outage Events

\begin{tabular}{|l|l|c|}
\hline Reason For Outage & Cause of Problem or Event & No. \\
\hline Calibration drift & $\begin{array}{l}\text { MAC capacitance level probes needed } \\
\text { recalibration }\end{array}$ & 3 \\
\hline Mechanical failure & $\begin{array}{l}\text { Sorbent heater grid warpage, grid hole } \\
\text { pluggage \& blown rupture disk }\end{array}$ & 2 \\
\hline Mechanical failure & Regenerator control valve improperly seated & 2 \\
\hline Mechanical failure & Hole in incinerator off-gas duct at steam inlet & 2 \\
\hline Electrical failure & $\begin{array}{l}\text { MAC level probe failed due to disconnected } \\
\text { wire }\end{array}$ & 1 \\
\hline Mechanical failure & Top J-valve fluidizing grid plugged & 1 \\
\hline Mechanical failure & Flue gas fan bearings needed lubrication & 1 \\
\hline Mechanical failure & Acid line clog caused adsorber grid pluggage & 1 \\
\hline Electrical failure* & Power outage & 1 \\
\hline Plant modification & DCS reconfiguration & 1 \\
\hline Plant modification & $\begin{array}{l}\text { Incinerator damper and control loop } \\
\text { modifications }\end{array}$ & 1 \\
\hline Planned shutdown & $\begin{array}{l}\text { Sorbent heater grid warpage and grid hole } \\
\text { pluggage }\end{array}$ & 2 \\
\hline Operating conditions & Oversulfation of sorbent & 1 \\
\hline Operating conditions & $\begin{array}{l}\text { Adsorber grid pluggage caused by acid } \\
\text { carryover }\end{array}$ & 1 \\
\hline Operator error & Incinerator malfunction & 2 \\
\hline Operator error & Regenerator level gauge accidently shut off & 1 \\
\hline Calibration & MAC calibration & 2 \\
\hline Power plant & Power plant off line & 1 \\
\hline Holiday & Thanksgiving \& Christmas & 2 \\
\hline Project review & Process shutdown & 1 \\
\hline & & 2 \\
\hline
\end{tabular}

* Relevant failures for projected commercial availability calculations of Table 3-2. 
Table 3-2. Pilot Plant Gross Availability

\begin{tabular}{|lc|}
\hline April-December 1992, total hours & 6600 \\
Less host flue gas interruptions & $\underline{358}$ \\
Host flue gas supply time & 6242 \\
Less all outages: & \\
NOXSO staff holidays & 332 \\
Project review days & 138 \\
DCS and incinerator modifications & 48 \\
Test envelope "events" & 77 \\
Test calibration shutdowns & 21 \\
Operator induced trips & 14 \\
Heater modification shutdowns & 278 \\
System checks and mechanical/electrical & \\
outages \& repairs & $\underline{63}$ \\
$\quad$ Total hours & 1561 \\
Time on flue gas & 4681 \\
Gross Availability (4681/6242) x 100\% & $75 \%$ \\
\hline
\end{tabular}

\subsubsection{Pilot Plant Net Availability}

The pilot plant net availability is calculated considering the pilot plant as a commercial venture, in other words, as if the operations attempted to maximize availability. The result of this view is that the calculated time the plant is not available includes time in which the plant was mechanically unable to process flue gas, due to either equipment failures or trips, but excludes: those failures related to equipment needed solely for pilot plant operations (e.g. regenerator off-gas incinerator, which would not be present in a commercial system), tests which measured the limits of the process performance envelope, outage periods for equipment modifications or calibrations, project staff review meeting days, and staff holidays. The downtimes falling under these categories are considered as time that would have been spent on flue gas in a commercial environment. Consequently, the pilot plant net availability was calculated at $97 \%$, as shown in Table 3-3. 
Table 3-3. Pilot Plant Net Availability

\begin{tabular}{|lc|}
\hline Host flue gas supply time, hours & 6242 \\
Less outages not due solely to tests*: & \\
& \\
Operator induced trips & 87 \\
Heater shutdowns & \\
Mechanical/electrical outages & 96 \\
repairs and repairs & 188 \\
Total hours & 6054 \\
Adjusted POC time on flue gas & $97 \%$ \\
POC Net Availability (6054/6242) x 100\% & \\
& \\
*Excludes failures of equipment unique to the pilot plant, \\
equipment failures in pushing the performance envelope, planned \\
outages for plant modifications, and other outages listed: \\
NOXSO staff holidays & 332 \\
Project review days & 138 \\
DCS and incinerator modifications & 48 \\
Test envelope "events" & 77 \\
Test calibration shutdowns & 21 \\
Operator induced trips & 9 \\
Heater modification shutdowns & 191 \\
System checks due to mechanical/electrical & \\
outages & 557 \\
& 1373 \\
\hline
\end{tabular}

The mechanical and electrical failures, and the system trips were analyzed on a case by case basis to determine the effect of each event on the net availability. In each case, the total down time was divided into actual repair time and the follow up time for system checks and other modifications. The downtime in each case was then adjusted so that only the time used for repairs is counted against the net availability. The remainder of the time is considered as time which would have been spent on flue gas under normal, commercial operating circumstances. 


\subsubsection{Failure Analysis}

Several pilot plant problems have been solved through design iterations which eliminate the potential of these problems recurring at commercial installations. The design solutions to the outages listed in Table 3-1 are presented here, and summarized in Table 3-4.

Table 3-4. Design Changes Based on Pilot Plant Performance

\begin{tabular}{|l|l|}
\hline Problem & Solution \\
\hline Warpage of sorbent heater grids & Grids redesigned for differential thermal expansion \\
\hline $\begin{array}{l}\text { Pluggage of sorbent heater grid } \\
\text { holes }\end{array}$ & $\begin{array}{l}\text { Sorbent heater designed for correct TDH between } \\
\text { grids }\end{array}$ \\
\hline Pluggage of J-valve fluidizing grid & J-valves replaced with L-valves \\
\hline $\begin{array}{l}\text { Unseated regenerator pressure } \\
\text { control valve }\end{array}$ & $\begin{array}{l}\text { Off-gas lines designed with redundant valve in } \\
\text { parallel }\end{array}$ \\
\hline $\begin{array}{l}\text { Blown rupture disk in sorbent } \\
\text { heater disengaging vessel }\end{array}$ & $\begin{array}{l}\text { No sorbent heater disengaging vessel in commercial } \\
\text { design }\end{array}$ \\
\hline $\begin{array}{l}\text { Calibration drift in dense phase } \\
\text { transport capacitance level probes }\end{array}$ & Switch to vibrating wand probe \\
\hline $\begin{array}{l}\text { Frequent lubrication of } 3600 \text { rpm } \\
\text { direct drive fan bearings }\end{array}$ & $\begin{array}{l}\text { Low speed utility service fans will eliminate } \\
\text { problem }\end{array}$ \\
\hline $\begin{array}{l}\text { Adsorber grid pluggage by acid } \\
\text { line clog }\end{array}$ & In-bed cooling eliminates the need for the acid line \\
\hline Various incinerator failures & $\begin{array}{l}\text { No incinerator needed for commercial service. } \\
\text { specinerator needed for the sulfur recovery unit is }\end{array}$ \\
\hline
\end{tabular}

The sorbent heater at the pilot plant created several outages, but they were mechanical in nature and not process flaws. First, there was the thermal expansion which caused the grids to warp and restrict movement of the flapper valves of the downcomers. This was due to the grid sections being welded together and spot welded to supports which anchored them to the vessel walls not allowing for thermal expansion. The redesign of the grids, and their construction, for commercial plants includes rolled edges and vertical clamping of the grid sections. This will allow the grid holes to be continued across the joints without loss of fluidization area. By clamping the grid outer edges between rolled angles with bolts and bolting 
the center support angles to support shoes, the design allows for differential thermal expansion without buckling of the material. This construction technique has been successfully tested at the pilot plant when the second grid was added to the adsorber vessel. The other problem which plagued the sorbent heater, grid hole pluggage, was a result of insufficient transport disengaging height (TDH) between the fluidized bed and the grid above it. This problem is solved by providing adequate $\mathrm{TDH}$.

The J-valves are dilute phase transport devices which serve a dual purpose of transporting the sorbent from vessel to vessel while forming a seal to prevent the mixing of gases between vessels. The primary problem with the design is the use of internal distributor plates which plugged over time resulting in a degradation of valve performance. The solution to this problem was the design, testing, and integration of an L-valve. The L-valve, which was also successfully tested at the pilot plant, has no internal grids; it also proved to be simpler in design, more reliable in performance, easier to control, and its gas requirements are essentially the same as the J-valves.

When the rupture disk failed in the sorbent heater disengaging vessel it was because of sorbent heater and $\mathrm{J}$-valve problems. If sorbent could not move through the heater and into the regenerator, it backed up into the disengaging vessel causing elevated pressures which ruptured the disk. The disengaging vessel was supplied as part of the dense phase transport system and through the operation of the pilot plant was found to have no practical value to the NOXSO Process. Commercial designs will not include a sorbent heater disengaging vessel.

The pressure control valve in the regenerator off-gas lines also caused flue gas outages. These outages were due to the valve being improperly seated. While this type of problem may occur at a commercial installation, the off-gas lines in the commercial unit are designed with a redundant valve in parallel which would automatically be placed into service in the event of a failure in the primary valve.

The capacitance level probes used in the dense phase transport system had a quick recalibration procedure requiring only that the operator empty the fluidizing vessel and then hold a button in for about 20 seconds in the sensing module electronics enclosure. The problem with these probes was that they would frequently experience calibration drift to the point of failure. Vibrating wand type level probes were also used at the pilot plant in other services with little or no trouble at all, thus it will be this type of probe which will be used in the dense phase transport service of commercial plants.

Both of the fans used at the pilot plant operated at $3600 \mathrm{rpm}$ and experienced failures due to the high speeds and lack of vibration monitoring equipment. By using low speed, utility service fans these problems will be avoided at commercial installations.

The problem which caused the adsorber grid pluggage has been eliminated by in-bed cooling. With duct cooling, there was acid formation upstream of the adsorber which had to be removed by an acid line. When a clog developed in an elbow of that line, acid backed up into the duct and was carried into the adsorber, plugging the grid. In-bed cooling precludes the 
formation of acid upstream of the adsorber since the temperature of the flue gas is maintained above the acid dewpoint in the ductwork.

The incinerator was a bottom fired vessel which burned the regenerator off-gas to convert all sulfur species to $\mathrm{SO}_{2}$ to return to the power plant stack. However, the incinerator had several problems at the pilot plant (it was not specifically designed for this service), this incinerator is not required in a commercial plant in which the regenerator off-gas is fed to a sulfur recovery unit.

\subsubsection{Projected Commercial Plant Availability}

The projected availability of a commercial system was calculated assuming commercial operating conditions and incorporation of the design improvements from the pilot plant test program. Because a commercial unit will not be intentionally stressed to evaluate component performance as was done at the pilot plant, it is anticipated that commercial service will be much less severe. Also, institution of the proposed design improvements will preclude repeating many of the problems which were experienced at the pilot plant. Those events in Table 3-1 marked with an asterisk are relevant to this calculation. Results of this calculation project commercial availability to be greater than $99 \%$, as shown in Table 3-5.

Table 3-5. Projected NOXSO Commercial Plant Availability

\begin{tabular}{|c|c|}
\hline Equivalent host flue gas supply time, hours & 6242 \\
\hline \multicolumn{2}{|l|}{ Projected commercial outages*: } \\
\hline Operator induced trips & 5 \\
\hline Mechanical/electrical outages and repairs & 11 \\
\hline Total hours & 16 \\
\hline Projected time on flue gas & 6226 \\
\hline $\begin{array}{l}\text { Predicted NOXSO Commercial Availability } 6226 \\
>99 \%\end{array}$ & \\
\hline
\end{tabular}

\subsubsection{Equipment Sparing}

As estimated in the previous section, the availability of the commercial NOXSO plant will be greater than $99 \%$. To accomplish this high level of availability, installed spares will be provided as indicated in Table 3-6. Spared equipment is categorized as rotating equipment, control valves, and solids transport systems. A brief discussion of the equipment sparing by category follows. 
Table 3-6. Equipment Sparing

\begin{tabular}{|l|c|}
\hline Rotating Equipment & $2 \times 60 \%$ \\
\hline Booster Fans & $3 \times 50 \%$ \\
\hline Heater/Cooler Fans & \\
\hline Air Compressors & $2 \times 50 \%$ \\
\hline Low Pressure & $2 \times 100 \%$ (spare for L.P. and H.P) \\
\hline High Pressure & $2 \times 100 \%$ \\
\hline Boiler Feedwater Pump & \\
\hline Control Valves & Automatic valve in parallel \\
\hline Severe Service & Manual valve in parallel \\
\hline Normal Service & \\
\hline Solids Transport & $2 \times 60 \%$ \\
\hline Dense Phase & $2 \times 60 \%$ \\
\hline L-Valves & \\
\hline Sulfur Plant & $2 \times 100 \%$ \\
\hline Booster Fan & $2 \times 100 \%$ \\
\hline Combustion Fan & $2 \times 100 \%$ \\
\hline Oil Pump & $2 \times 100 \%$ \\
\hline Sulfur Pump & \\
\hline
\end{tabular}

\subsubsection{Rotating_Equipment}

In general, all rotating equipment will be spared. The sorbent heater/cooler air will be provided by two of three $50 \%$ capacity fans. The boiler feedwater to the $\mathrm{NO}_{\mathrm{x}}$ recycle cooler will be provided by one of two $100 \%$ capacity pumps. A second $100 \%$ capacity 100 psig air compressor (for instrument air) will provide a spare for the 100 psig air compressor as well as for either of the two $50 \%$ capacity 50 psig air compressors used for the dense phase transport system and air driven L-valves. The two adsorbers will each be served by one $60 \%$ capacity fan. If one flue gas booster fan fails, the remaining flue gas train will be isolated and the NOXSO plant capacity will be reduced to the $60 \%$ capacity of a single train. 
In the sulfur plant, the rotating equipment is also spared. The booster fan and combustion air blower are each provided with a $100 \%$ capacity spare. Also, the oil circulation pump and the main sulfur tank pump are each provided with a $100 \%$ capacity spare.

\subsubsection{Control Valves}

All control valves will be equipped with isolation valves and at least a manual throttle valve in parallel with the primary valve. In the event of a failure, the plant could continue to operate by manually regulating the spare valve while the automatic valve is repaired. Those valves which could not be manually regulated, in the event of a failure in the primary valve, will be provided with an automatic valve in parallel.

\subsubsection{Sorbent Transport Systems}

The dense phase transport system which transports sorbent from the adsorbers to the sorbent heater is comprised of two fluidizers and control valves for each adsorber. In the event that one of these fails, sorbent circulation can be maintained at a slightly reduced rate; however, the sorbent circulation rate would be higher to one adsorber than the other. The dilute phase transport systems which transport sorbent from the sorbent heater to the regenerator, from the regenerator to the sorbent cooler, and from the sorbent cooler to the surge tank, will each be equipped with two $60 \%$ capacity L-valves.

\subsection{Nitrogen Oxide Studies}

No nitrogen oxide studies were conducted during this reporting period.

\subsection{Process Studies}

\subsubsection{Sorbent Heater/Cooler Energy Balance}

Recent process studies of the sorbent heater and sorbent cooler energy balances have attempted to quantify water adsorption on the NOXSO sorbent, while examining the effect of water adsorption/desorption on the design of the sorbent heater/cooler train of the demonstration plant.

Previously, it was proposed that water adsorption and desorption in the sorbent cooler and sorbent heater, respectively, were the cause for the deficient energy balance closures experienced at the pilot plant. This proposal has been verified through an examination of heat utilization efficiencies and by an uncertainty analysis (presented in Quarterly Technical Report No. 11). In order to fully quantify this effect, it is necessary to experimentally generate a set of water adsorption isotherms specific to the NOXSO sorbent. This would require an extensive laboratory effort. In order to obtain more immediate data, laboratory adsorption tests simulating water adsorption in the adsorber using NOXSO low density sorbent will be conducted. This will provide adsorption data points which may be used to reconcile the sorbent heater energy balance 
by quantifying the water content of sorbent entering the sorbent heater. These laboratory tests are in progress.

A study has been conducted which examines the effect of water adsorption on the design of the sorbent heater/cooler train. This analysis uses the most recent computer simulation of the NOXSO process to obtain demonstration plant stream data with no water adsorption/desorption taking place. By individually treating the sorbent heater and sorbent cooler, water desorption and adsorption are included in a heat transfer analysis to determine the effect on the required gas mass flows and vessel off-gas temperatures. The methods, assumptions, and results of this study are presented next.

This study relies on the computer simulation to provide the data which forms the starting point for the water adsorption/desorption analysis. The simulation provides information for the sorbent heater and sorbent cooler, including: the number of vessel stages, the sorbent mass flow rates, the sorbent inlet temperatures, the sorbent outlet temperatures and the gas inlet temperatures. As water adsorption/desorption is included in the analyses, the object is to find the gas mass flows and off-gas temperatures at which the systems reach thermodynamic equilibrium for each value of water content of sorbent entering the heater or exiting the cooler.

Assumptions made for the analyses are as follows. Each fluid bed is treated as two continuous stirred tank reactors (CSTR) in series. The gas does not mix between the stages. In the case of the sorbent heater, all of the water is considered to be desorbed in the top stage; In the case of the sorbent cooler, all of the water is considered to be adsorbed in the bottom stage. Also, the water heat of adsorption is considered to be a constant equal to $1250 \mathrm{Btu} / \mathrm{lb}$. Finally, in these analyses, ambient heat losses are not included; ambient losses have been shown to be about one percent of the heat input of the system, and for these analyses this is considered inconsequential.

By performing an energy balance around each fluidized bed in the vessels, the following equations are developed. In the analysis of the sorbent heater, the following two equations are used.

For the top bed, in which water desorption is taking place,

$$
m_{s} * c_{p_{s}} *\left(T_{s_{o}}-T_{s_{t}}\right)+m_{s} * X_{H 2 O} * h_{A_{H 2 O}}=m_{g} * c_{p_{g}} *\left(T_{g_{t}}-T_{g_{o}}\right)
$$

In the remaining three beds,

$$
m_{s} * c_{p_{s}} *\left(T_{s_{o}}-T_{s_{i}}\right)=m_{g} * c_{p_{g}} *\left(T_{g_{l}}-T_{g_{o}}\right)
$$

In the analysis of the sorbent cooler the following two equations are used:

For the bottom bed, in which water adsorption is taking place, 


$$
m_{s} * c_{p_{s}} *\left(T_{s_{l}}-T_{s_{o}}\right)+m_{s} * X_{H 2 O} * h_{A_{H 2 O}}=m_{g} * c_{p_{g}} *\left(T_{g_{o}}-T_{g_{l}}\right)
$$

In the remaining three beds,

$$
m_{s} * c_{p_{s}} *\left(T_{s_{l}}-T_{s_{o}}\right)=m_{g} * c_{p_{g}} *\left(T_{g_{o}}-T_{g}\right)
$$

In the above equations a subscript $\mathrm{s}$ indicates a sorbent variable and a subscript $\mathrm{g}$ indicates a gas variable, additionally:

$$
\begin{array}{ll}
\mathrm{m} & =\text { mass flow, } \mathrm{lb} / \mathrm{hr} \\
\mathrm{c}_{\mathrm{p}} & =\text { specific heat, } \mathrm{Btu} / \mathrm{lb} /{ }^{\circ} \mathrm{F} \\
\mathrm{T}_{\mathrm{i}} & =\text { inlet temperature, }{ }^{\circ} \mathrm{F} \\
\mathrm{T}_{\mathrm{o}} & =\text { outlet temperature, }{ }^{\circ} \mathrm{F} \\
\mathrm{X}_{\mathrm{H} 2 \mathrm{O}} & =\text { sorbent water loading, } \mathrm{lb}_{\mathrm{H} 2 \mathrm{O}} / \mathrm{lb}_{\text {sorbent }} \\
\mathrm{h}_{\mathrm{AH} 2 \mathrm{O}} & =\text { water heat of adsorption, Btu/l } \mathrm{H}_{\mathrm{H} 2 \mathrm{O}}
\end{array}
$$

Also, in each case the specific heats are calculated using the following two equations:

$$
\begin{aligned}
& c_{p_{s}}=\left[22.08+0.008971 * T-522500 / T^{2}\right] / 102 \\
& c_{p_{g}}=\left[6.8717+0.000844 * T-39417 / T^{2}\right] / 28.84
\end{aligned}
$$

where $\mathrm{T}$ is the logarithmic mean temperature in degrees Kelvin and $\mathrm{c}_{\mathrm{p}}$ is in $\mathrm{Btu} / \mathrm{lb} /{ }^{\circ} \mathrm{F}$.

The water content of sorbent entering the sorbent heater is determined by the adsorber temperature, flue gas water content, adsorber in-bed water sprays, and the sorbent water loading characteristics. The analysis was conducted for sorbent entering the sorbent heater with water contents ranging from 0 to 7 percent. This range spans the expected sorbent water content based on typical adsorber operating conditions and water adsorption characteristics for commercially available activated alumina. Sorbent exits the sorbent heater at $1150^{\circ} \mathrm{F}$ containing a negligible amount of water.

Sorbent enters the sorbent cooler at approximately $1000^{\circ} \mathrm{F}$ containing a negligible amount of water. In the sorbent cooler, ambient air is used to cool the sorbent, consequently the water content of the cooling air is determined by the ambient air temperature and humidity. For the cooler analysis, the amount of water adsorbed by the sorbent is varied from 0 to 3 percent which spans the expected range based on the range of ambient conditions, sorbent mass flow rate, cooling air flow rate, and water adsorption characteristics for commercially available activated alumina.

Figure 3-3 and Figure 3-4 show the results of these analyses for the sorbent heater and cooler, respectively. As seen in the figures, the overall effect on heating and cooling the sorbent 
Figure 3-3. Energy Balance Water Effect -

Sorbent Heater

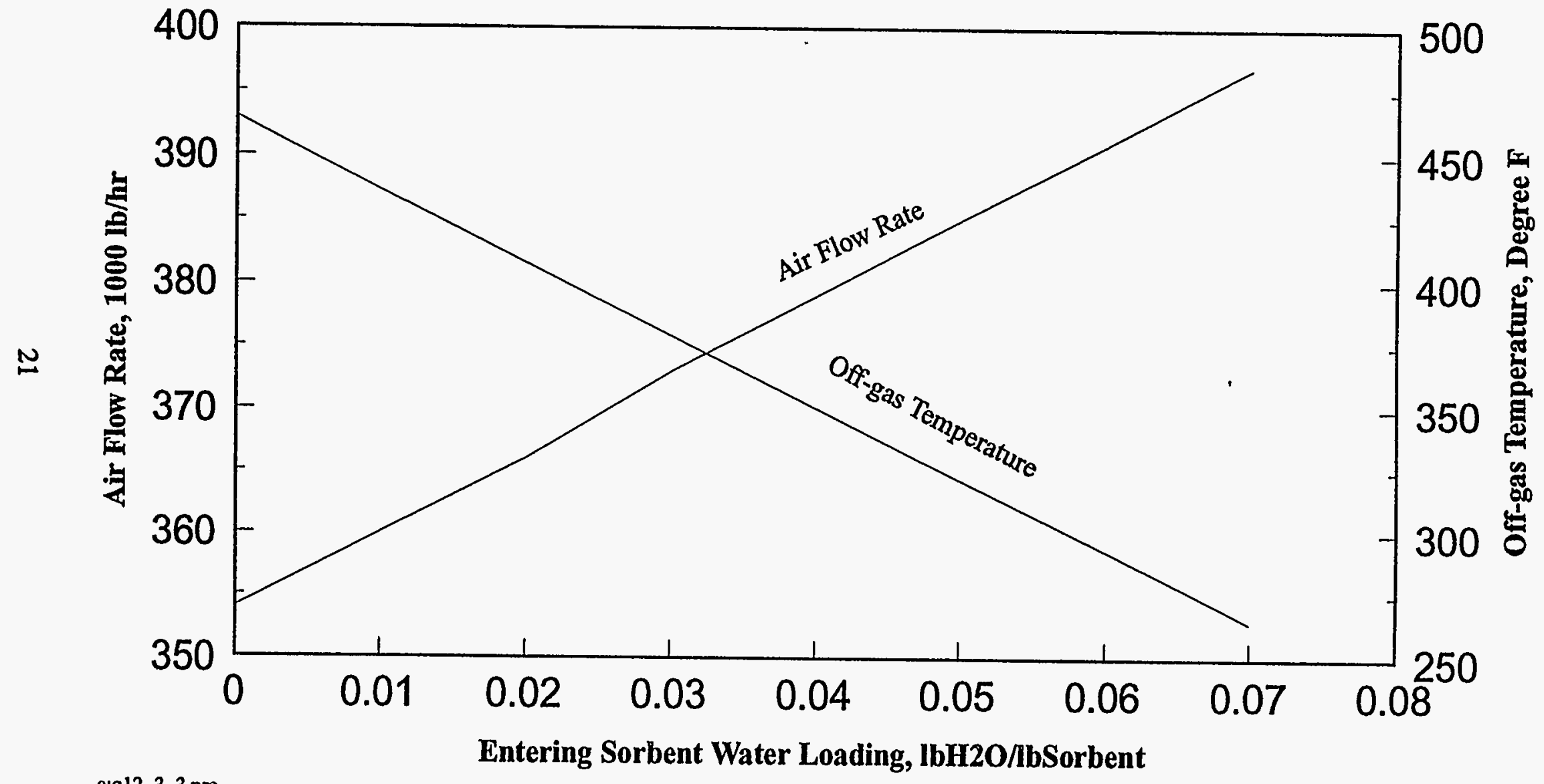

a:q12_3_3.pre 
Figure 3-4. Energy Balance Water Effect -

Sorbent Cooler

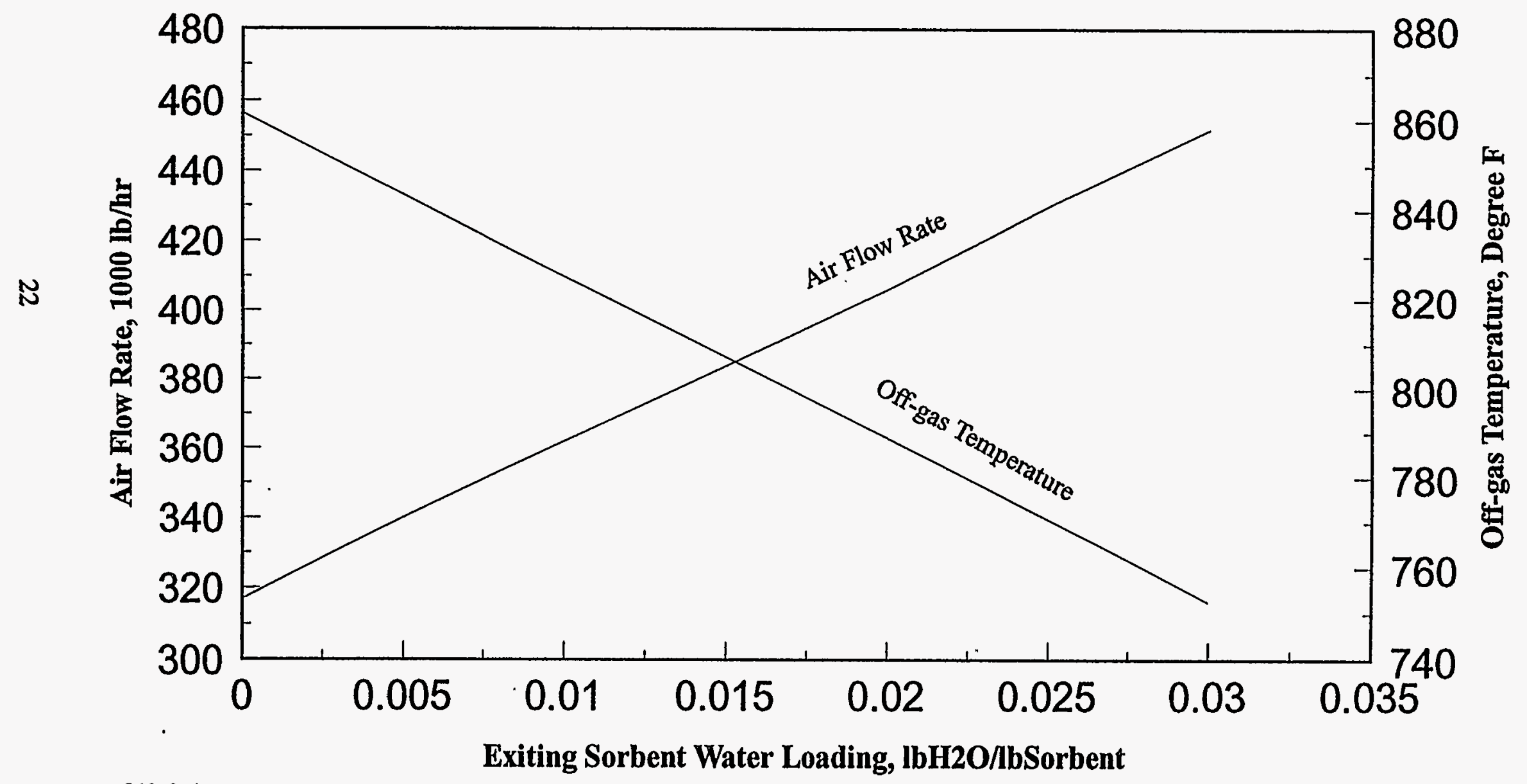


is similar in both cases. In the sorbent heater and sorbent cooler, as the amount of water desorbed or adsorbed respectively is increased there is an increase in the amount of gas required to heat or cool the sorbent as well as a decrease in the temperature of the off-gas stream. The effects of water adsorption and desorption on plant design include increased heater/cooler fan size and power consumption, increased natural gas consumption in the air heater, but also an increase in the energy credit generated by the sorbent heater off-gas stream. However, the overall impact on the capital and operating costs of the NOXSO process is small because the energy required to adsorb and desorb water is small compared to the total energy transferred in the sorbent heater and sorbent cooler.

\subsubsection{Adsorber Model}

Simulation of the Laboratory Fixed-Bed Sorption Data

In the last quarterly report, we summarized the work to simulate the $120^{\circ} \mathrm{C}$ fixed-bed sorption tests. Using the least-squares method, we determined the sorbent capacities for the $\mathrm{SO}_{2}$ and $\mathrm{NO}_{\mathrm{x}}$ sorption and the reaction rate constants at $120^{\circ} \mathrm{C}$. Similar work was conducted to simulate a $180^{\circ} \mathrm{C}$ fixed-bed sorption test. This time all eleven parameters, four sorption sites and seven rate constants, were determined from a single test. Since the resultant $180^{\circ} \mathrm{C}$ constants show some discrepancy with those from $120^{\circ} \mathrm{C}$, we repeated the least-squares fit with the $120^{\circ} \mathrm{C}$ data. The match between measured and simulated exit concentrations is excellent for both temperatures with the exception of the $\mathrm{NO}_{\mathrm{x}}$ concentration for the $120^{\circ} \mathrm{C}$ test as shown on Figure 3-5 and Figure 3-6. Even for $\mathrm{NO}_{\mathrm{x}}$ at $120^{\circ} \mathrm{C}$, the measured $\mathrm{NO}_{\mathrm{x}}$ is at worst $20 \%$ below the simulated value. This can possibly be attributed to temperature fluctuations in the experiments. At this time, we decided not to wait for the laboratory to repeat the tests, but to extend the modelling work to simulate the POC fluid-bed sorption data. Hopefully, the large scale data will help pinpoint the errors. The semi-final sorbent capacities and sorption rate constants obtained from the $120^{\circ} \mathrm{C}$ and $180^{\circ} \mathrm{C}$ fixed-bed data and used to generate the simulated results on Figure 3-5 and Figure 3-6 are tabulated in Figure 3-6. Clearly, the temperature has an important effect on the sorption. Both $\mathrm{NO}_{\mathrm{x}}$ and $\mathrm{SO}_{2}$ break through earlier at $180^{\circ} \mathrm{C}$ than for the case of $120^{\circ} \mathrm{C}$.

In general, the simulation results show that the sorption sites decrease with increasing temperature, while the sorption rate does the opposite. But two exceptions are found in Table 3-7. One, the alumina $\mathrm{SO}_{2}$ sorption sites, $\mathrm{Al}(1)$ increase with temperature. Two, the rate constant of $2 \mathrm{NaNO}_{3}+\mathrm{SO}_{2}-->\mathrm{Na}_{2} \mathrm{SO}_{4}+2 \mathrm{NO}_{2}$ reaction, $\mathrm{k} 9$, decreases with increasing temperature. We suspect the abnormal trend was caused by trying to determine too many parameters with too little laboratory data. 


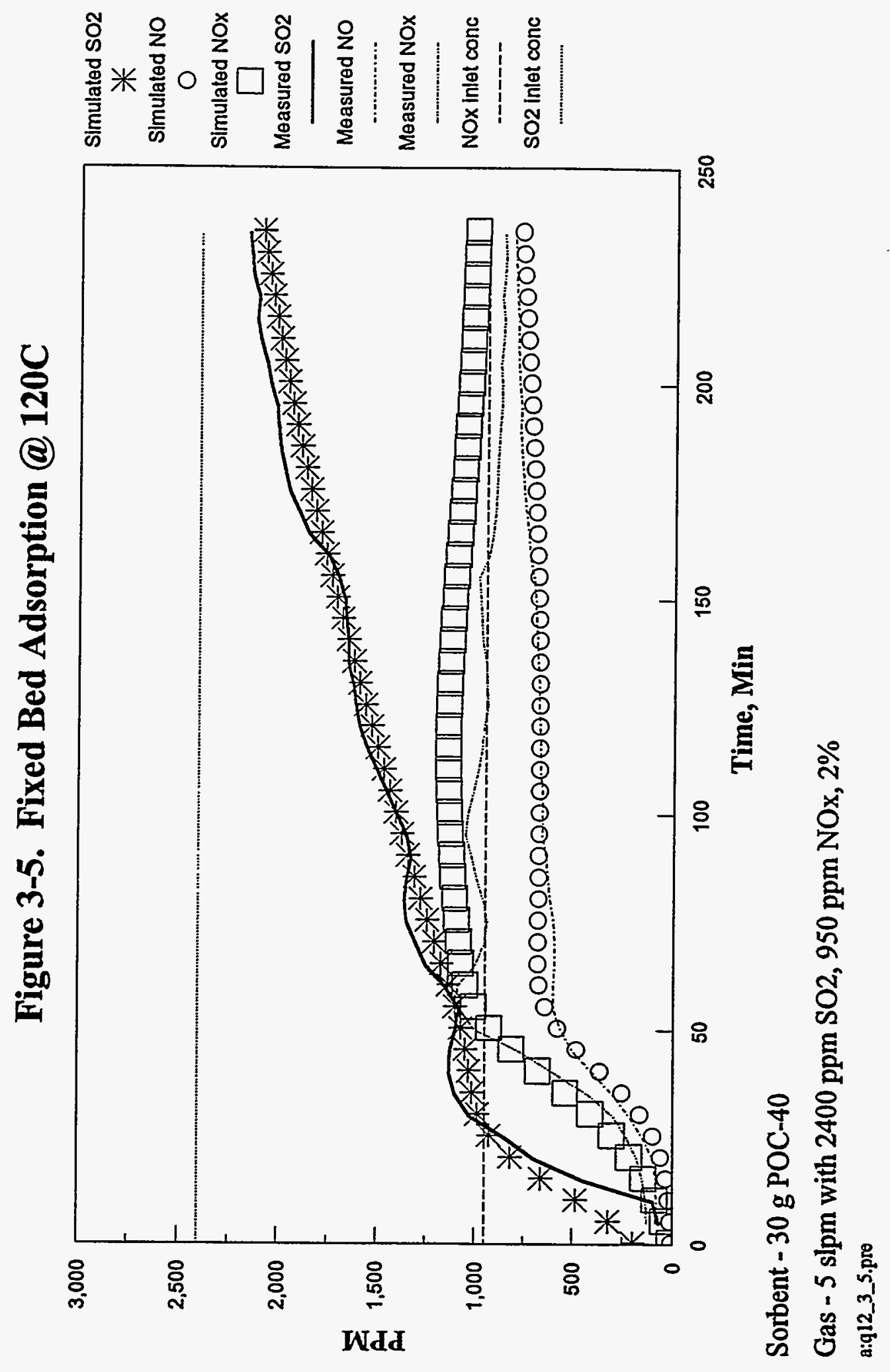


Figure 3-6. Fixed Bed Adsorption @180C

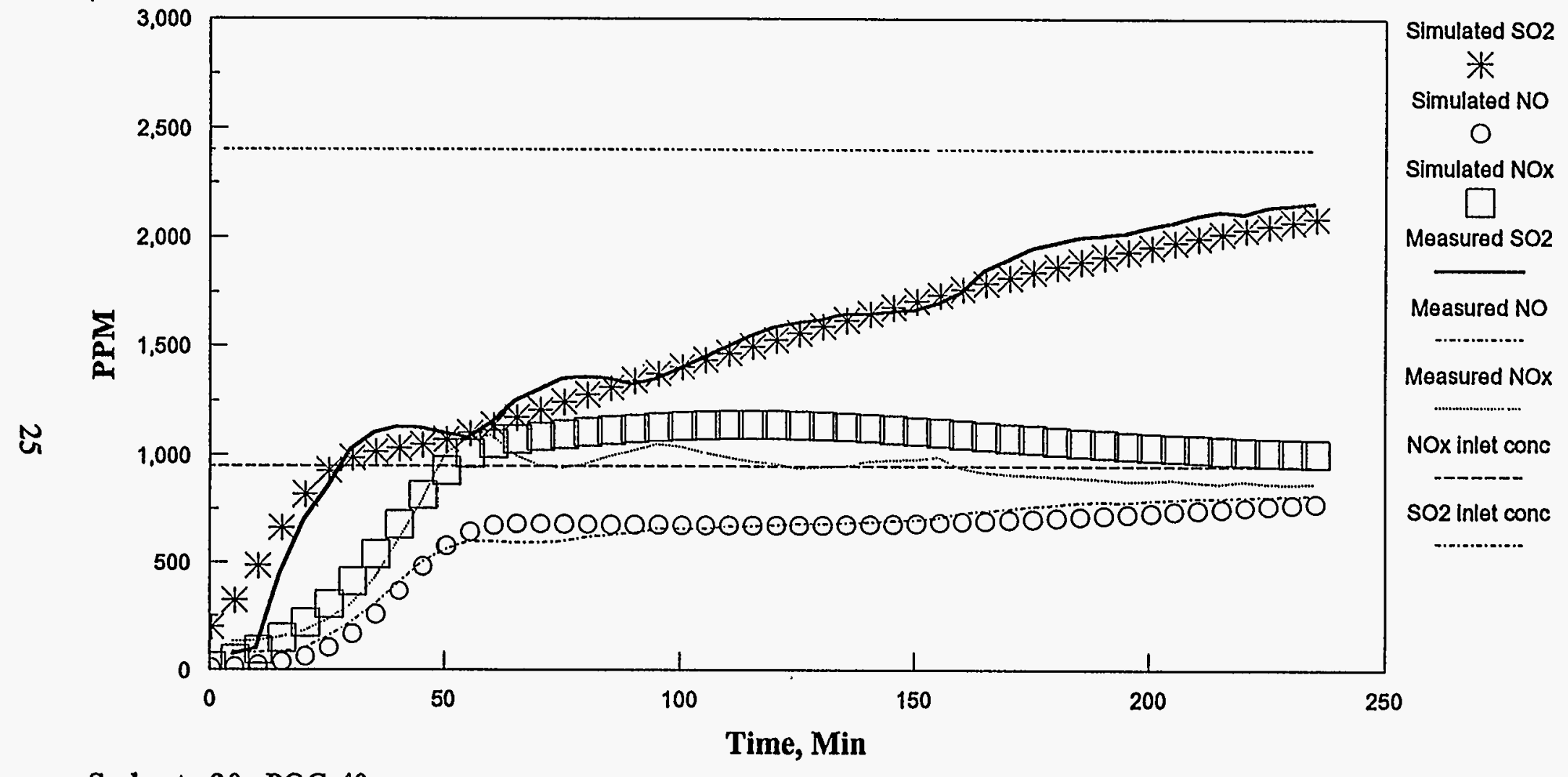

Sorbent - 30g POC-40

Gas - 5 slpm with 2450 ppm SO2, 965 ppm NOx, 2\%

a:q12_3_6.pre 
Table 3-7. Sorbent Capacities and Rate Constants for Sorption

\begin{tabular}{|c|c|c|}
\hline & $\mathbf{1 8 0}^{\circ} \mathbf{C}$ & $\mathbf{1 2 0}^{\circ} \mathbf{C}$ \\
\hline $\mathrm{Al}(1)$ & 0.9222 & 0.752 \\
\hline $\mathrm{Al}(2)$ & 0.3505 & 0.76 \\
\hline $\mathrm{Na}_{2} \mathrm{O}(1)$ & 3.7054 & 5 \\
\hline $\mathrm{Na}_{2} \mathrm{O}(2)$ & 0.0443 & 1.18 \\
\hline $\mathrm{k} 1$ & 1074.5237 & 681.2 \\
\hline $\mathrm{k} 2$ & 2881.9726 & 2210.85 \\
\hline $\mathrm{k} 4$ & 272.7469 & 132.6306 \\
\hline $\mathrm{k} 5$ & 14.2523 & 2.6455 \\
\hline $\mathrm{k} 6$ & $5.0472 \mathrm{E} 8$ & $5.0472 \mathrm{E} 8$ \\
\hline $\mathrm{k} 8$ & 7887.918 & 317.26 \\
\hline $\mathrm{k} 9$ & 7.3539 & 49.8196 \\
\hline
\end{tabular}

\section{Simulation of the POC Fluid-bed Sorption Data}

The POC adsorption data were obtained from a $10.5 \mathrm{ft}$ diameter fluidized-bed reactor. The POC tests were conducted with various operating conditions. The variables changed during the operation period were adsorber temperatures, sorbent inventories, gas and sorbent flow rates, $\mathrm{NO}_{\mathrm{x}}$ and $\mathrm{SO}_{2}$ inlet concentrations, with and without in-bed water spray, and single and two stage fluid-bed arrangements. This wide spectrum of test data serves as the best tool to verify the adsorber model. Before applying the parameter values obtained from the fixed-bed data to simulate the POC fluid-bed results, we have to approximate the temperature effect on the sorption. To keep the model simple, we assume the change of sorption sites is linearly proportional to the temperature change, and the changes of sorption rates obey Arrhenius' law.

The major difference between the fixed-bed and the fluid-bed is the gas-solid contact pattern. Theoretically, if there is a model to properly describe the gas-solid contact pattern in the fluid-bed, then there is a straight forward application to use the fixed-bed rate constants to simulate a fluid-bed reactor. Many such models are available in the literature, among them the bubbling-bed type models are the best. For the NOXSO fluid-bed adsorber, we selected the Bubble-Assemblage Model (BAM) to describe the gas-solid contact pattern. The BAM model was invented by C.Y. Wen and L.T. Fan', and generalized by M.H. Peters, L.S. Fan and T.L. Sweeney ${ }^{2}$. 
Figure 3-7. Comparison of SO2 Removal

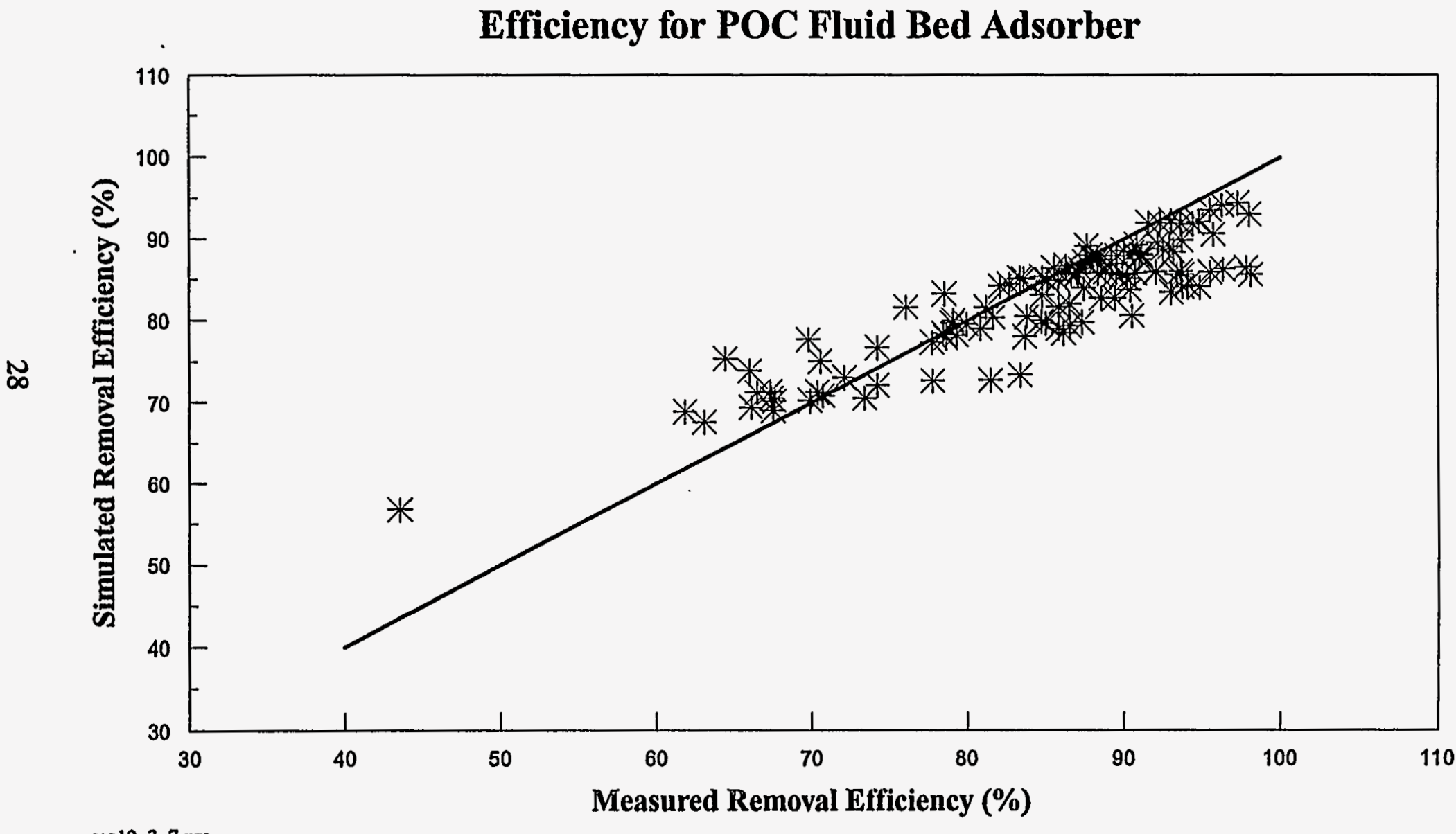

a:q12_3_7.pre 
Figure 3-8. Comparison of NOx Removal

Efficiencies for POC Fluid Bed Adsorber

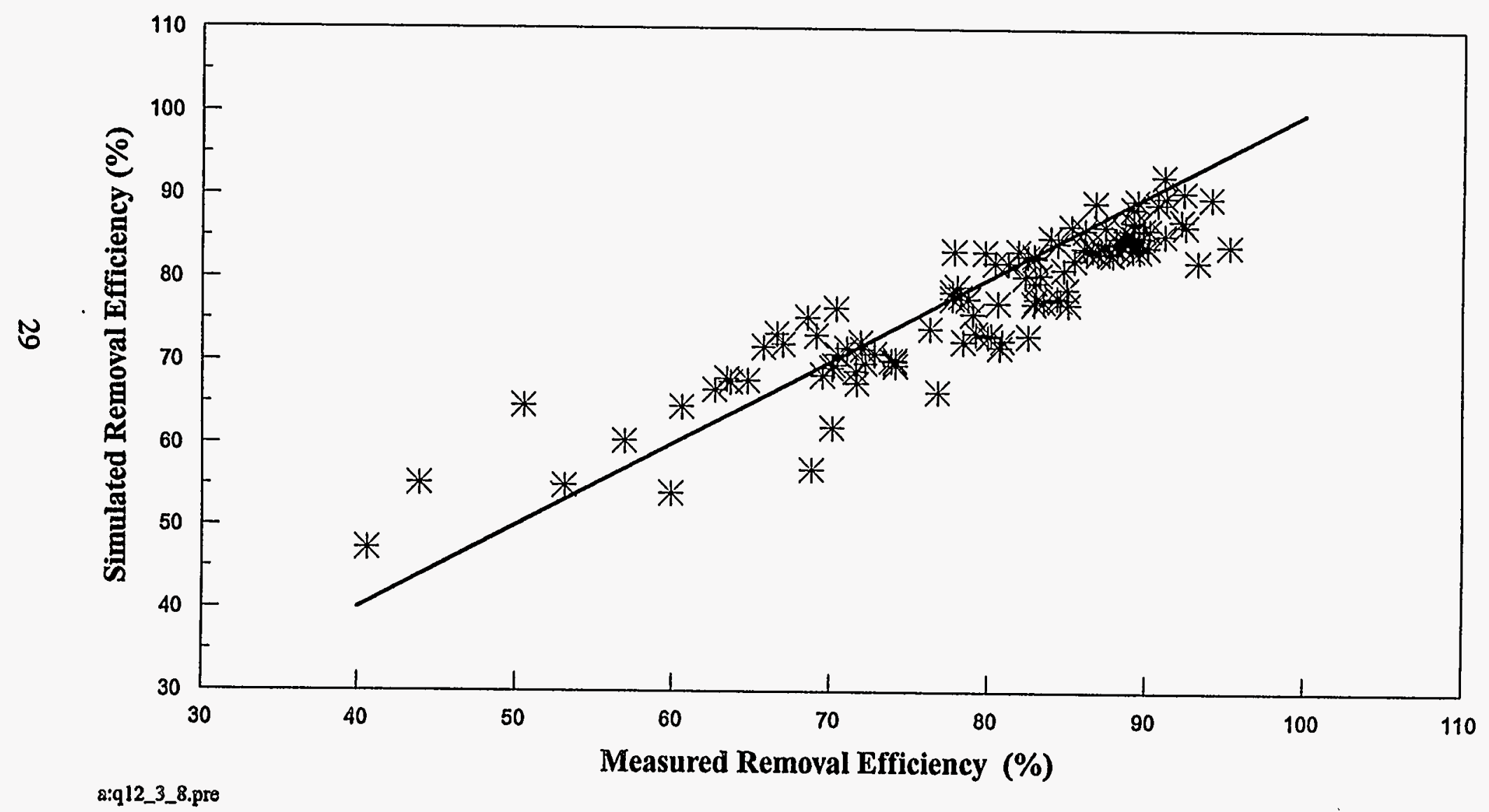

a:q12_3_8.pre 


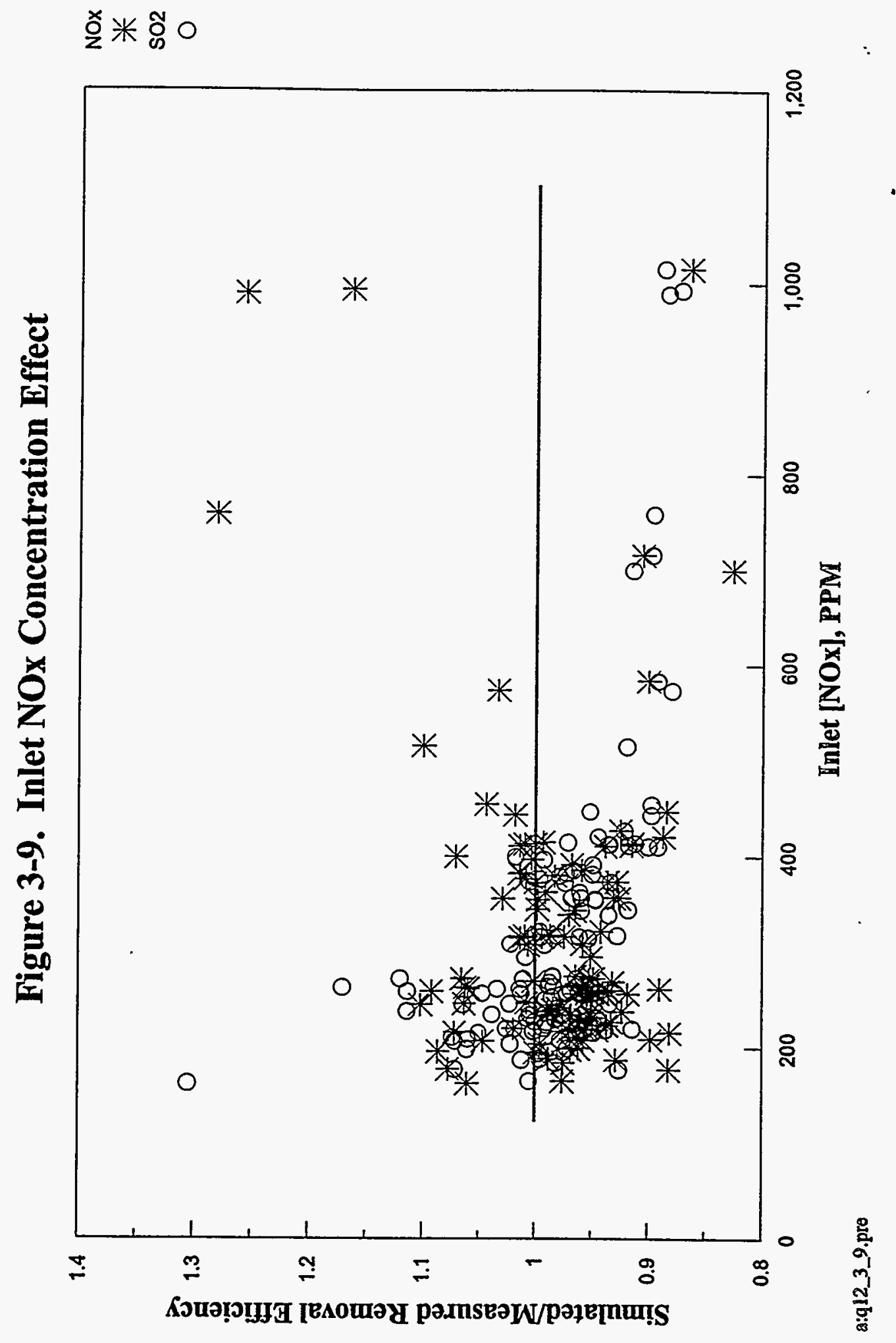




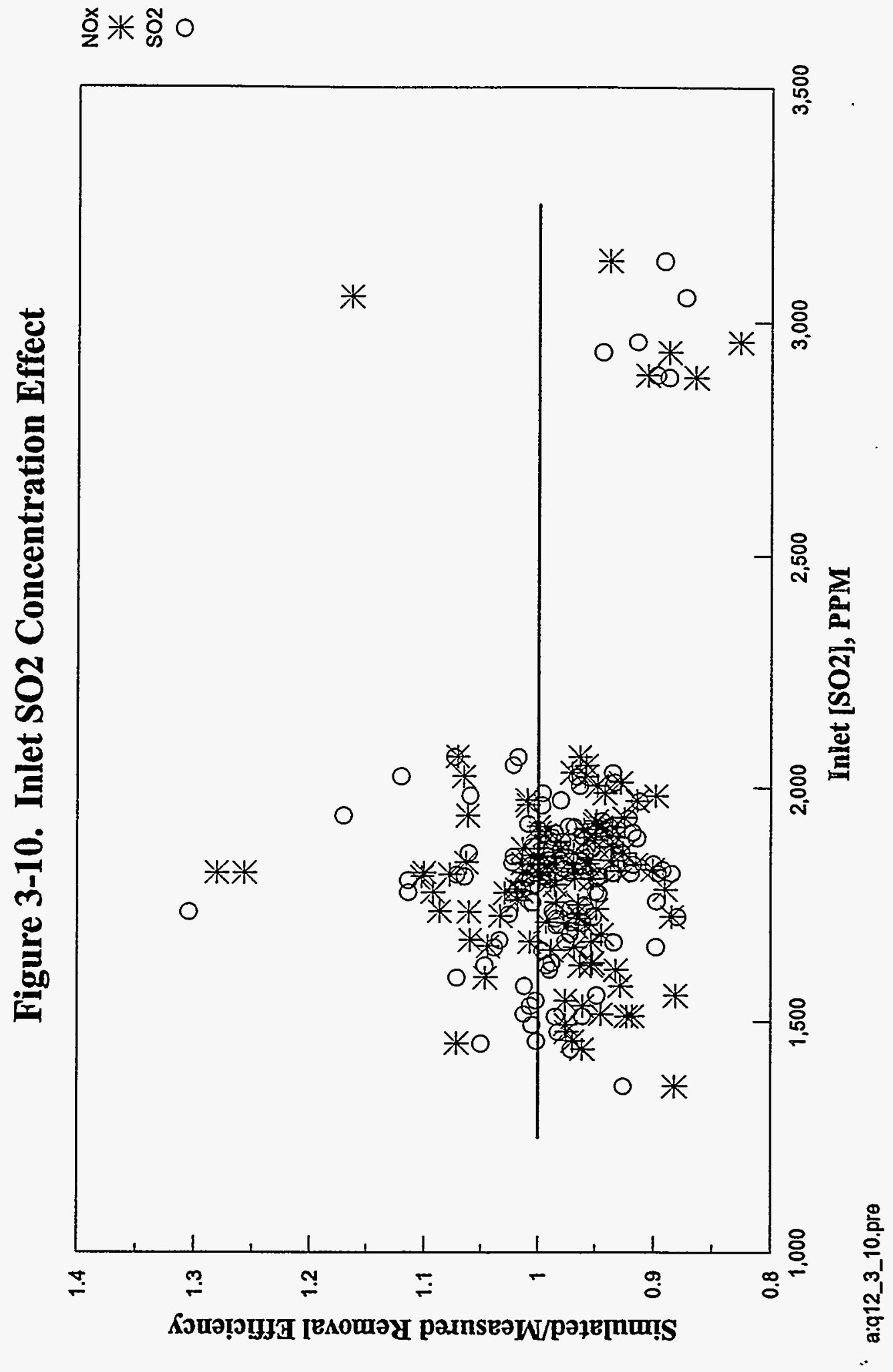




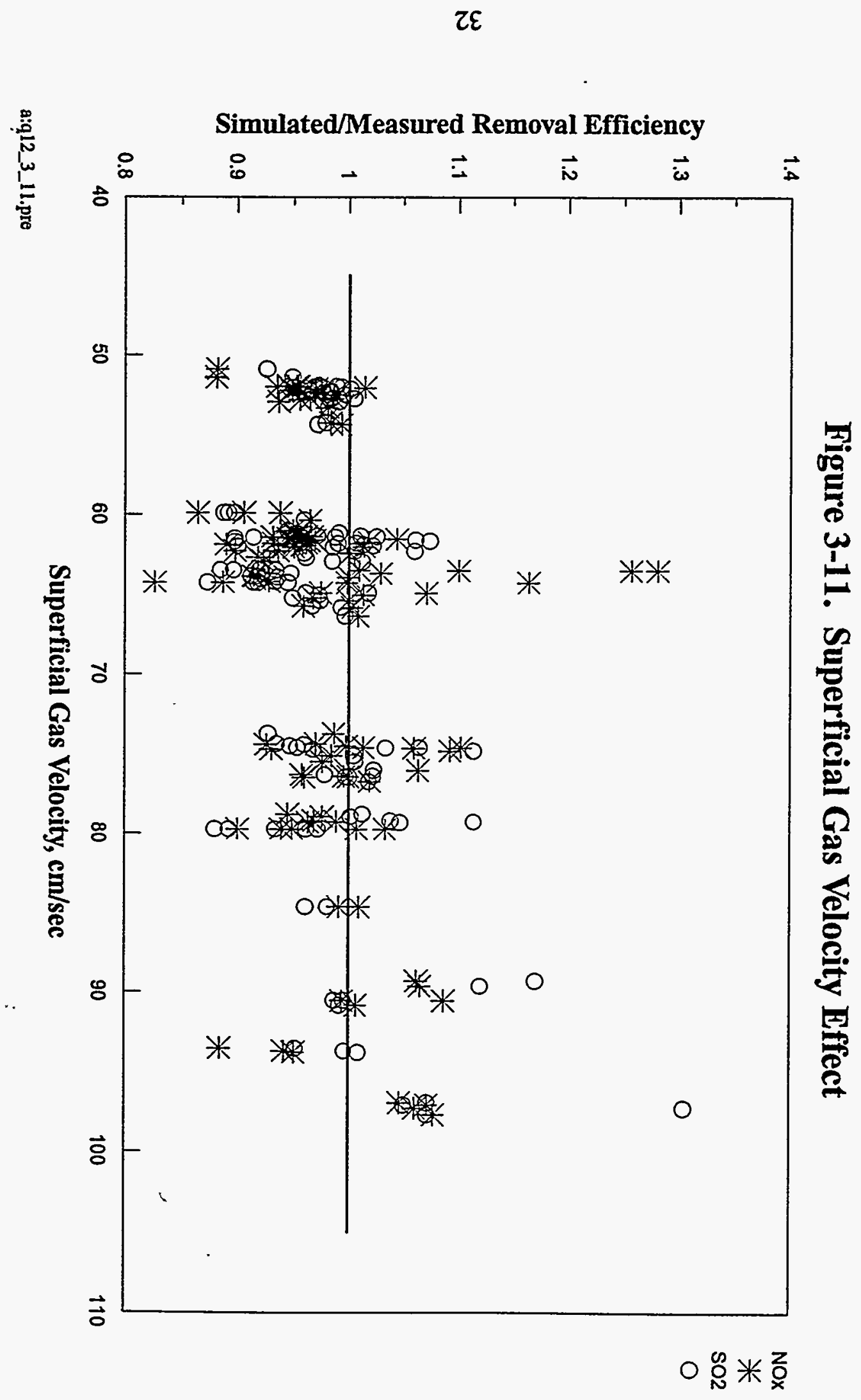




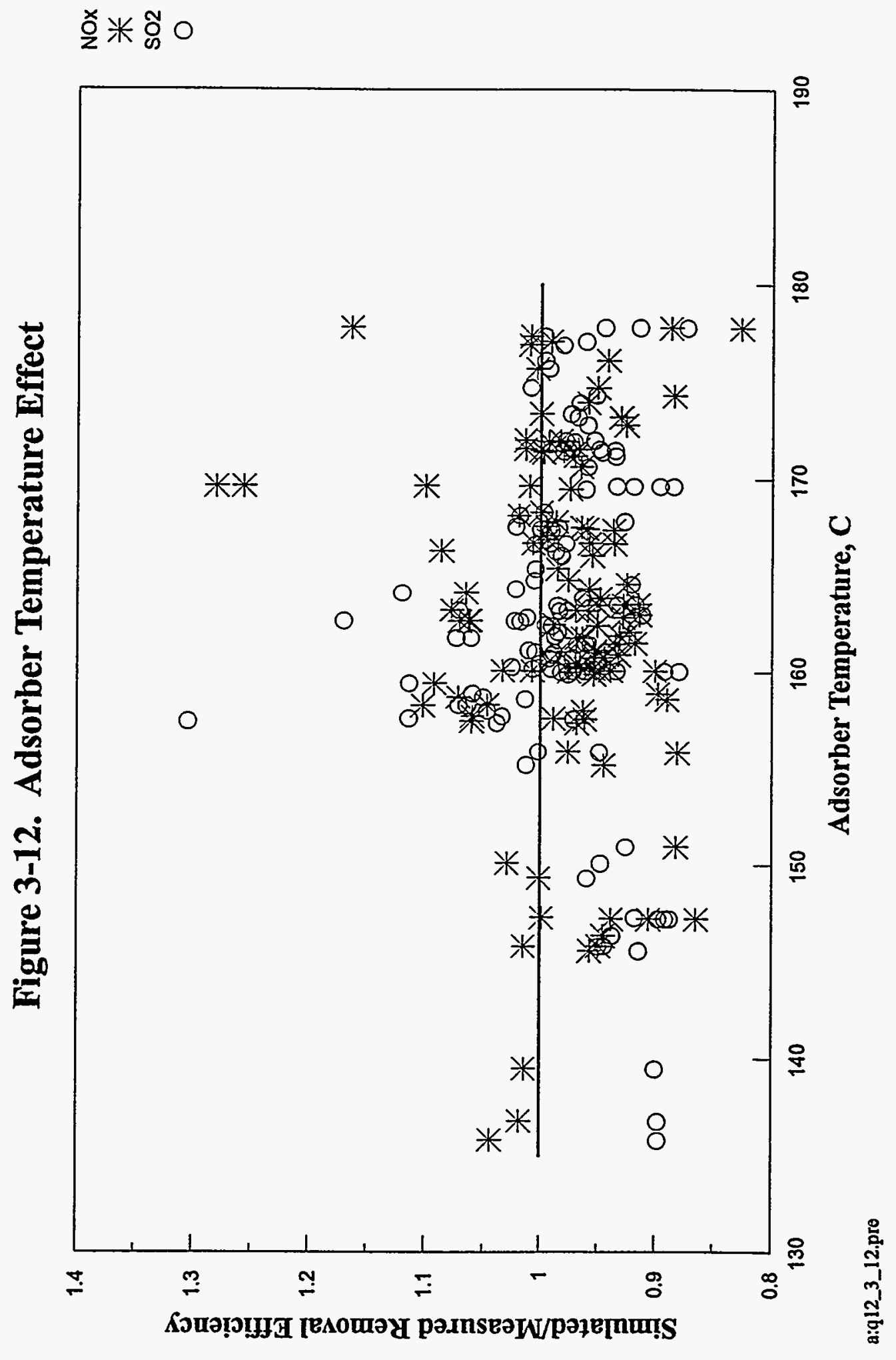




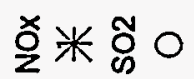

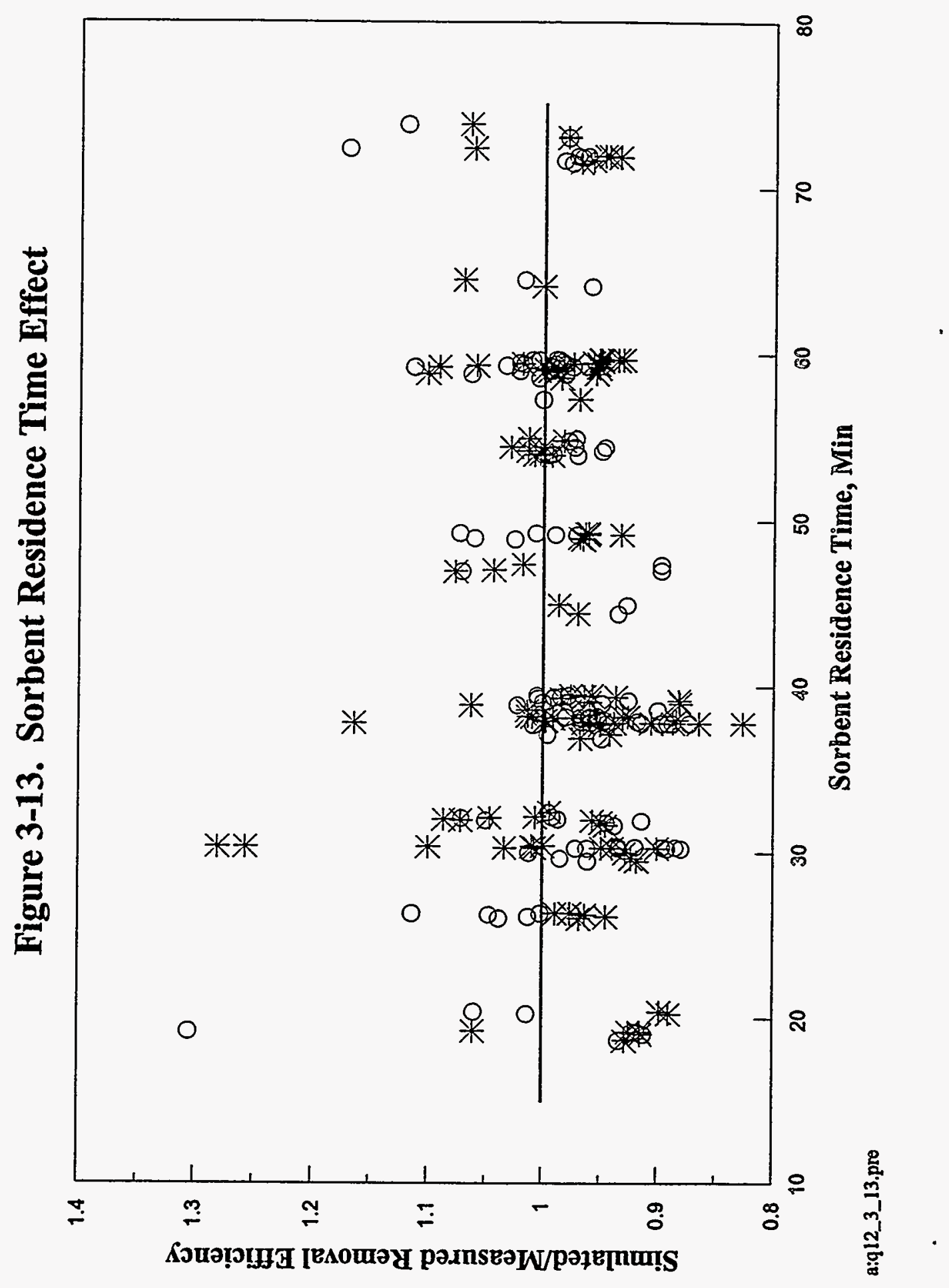


Figure 3-14. Gas-solid Contact Time Effect

(time for gas flow through the settled bed)

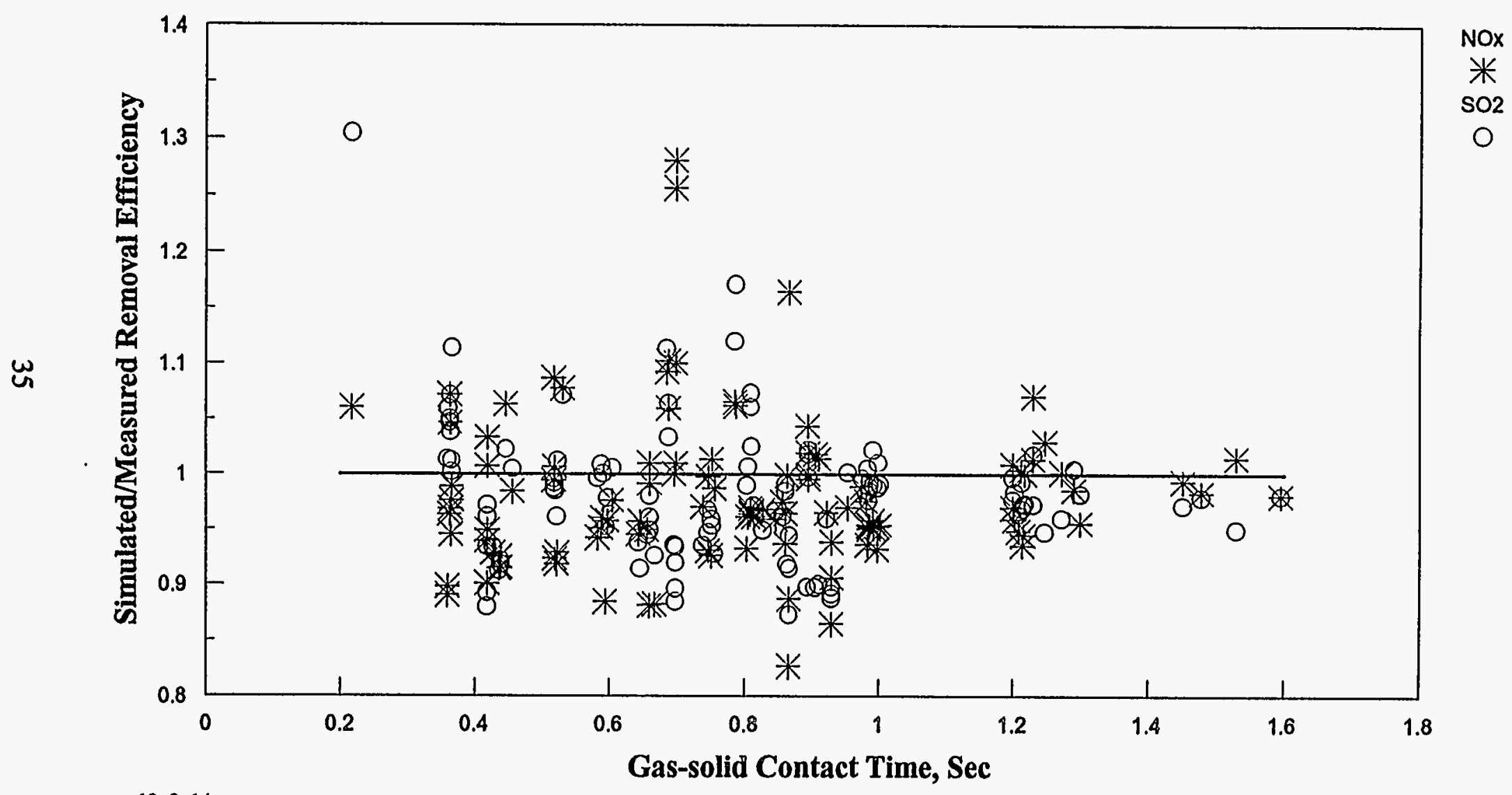

a:q12_3_14 
Figure 3-15. POC Adsorber NO and NOx Emission

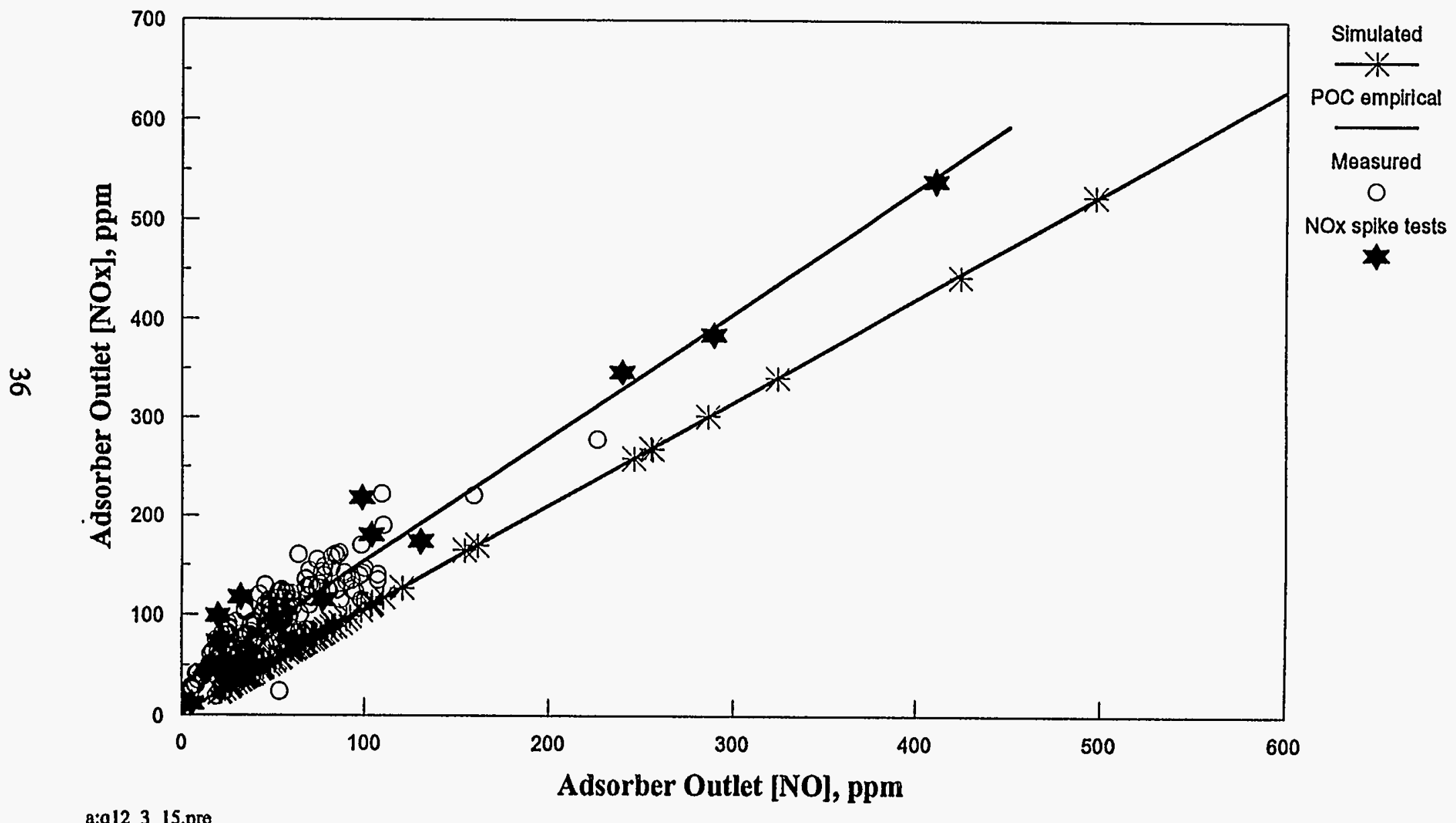


To further improve the adsorber model, we need additional laboratory data to assess the $\mathrm{NO}_{2}$ sorption. Until new laboratory data is available, the adsorption reaction model will remain unchanged. To make the adsorber model more useful, an empirical correlation of the $\mathrm{NO}_{2}$ emissions from the POC adsorber with its $\mathrm{NO}_{\mathrm{x}}$ slip was developed. Combining this empirical correlation with the adsorber model helps the adsorber designer size the vessel and estimate the corresponding $\mathrm{NO}_{2}$ emissions.

The status of the adsorber model is summarized in the following statements.

1). The program for the adsorber model was developed and tested with the laboratory (2" fixed-bed) and POC (126" fluid-bed) test data.

2). The program requires only one adjustable parameter to scale up the laboratory results to predict the $\mathrm{NO}_{\mathrm{x}}$ and $\mathrm{SO}_{2}$ removal efficiencies for the POC tests.

3). The program fails to predict the $\mathrm{NO}_{2}$ emissions correctly. But an empirical $\mathrm{NO}_{2}$ emission correlation was available for the adsorber designer to estimate the $\mathrm{NO}_{2}$ emissions based on the amount of $\mathrm{NO}_{\mathrm{x}}$ slip through the POC adsorber.

4). Improvement of the adsorber model requires more laboratory data. Especially for the $\mathrm{NO}$ and $\mathrm{NO}_{2}$ sorption study.

\subsubsection{Process Simulation}

As discussed in Section 3.5.1, water adsorption on the sorbent in the sorbent cooler and adsorber and subsequent desorption in the sorbent heater has a measurable effect on the sorbent cooler and sorbent heater energy balances. The primary effect is to increase the gas flow rate through the sorbent cooler/heater train and to increase natural gas consumption in the natural gas fired air heater. The process simulation model code has been modified to include the adsorption/desorption of water onto or off of the sorbent in the appropriate process locations.

\subsubsection{Process Economics}

Based on Proof-of-Concept construction and operating experience and insight gained during the design of the commercial demonstration unit, a conceptual NOXSO process was developed for a $500 \mathrm{MW}$ coal-fired power plant. A NOXSO Process of this size, or larger, is able to realize economies-of-scale in equipment requirements and construction. The design criteria used in developing the conceptual $500 \mathrm{MW}$ NOXSO Process is shown in Table 3-8. The NOXSO Process would consist of four equal sized modules, each treating the equivalent of 125 MW of flue gas.

The NOXSO Process economic analysis is shown in Table 3-9. The NOXSO Process will reduce $\mathrm{SO}_{2}$ emissions by $98 \%$ to $0.09 \mathrm{lb} / \mathrm{mmBtu}$ and reduce $\mathrm{NO}_{\mathrm{x}}$ emissions by $85 \%$ to 0.12 $\mathrm{lb} / \mathrm{mmBtu}$. The total plant cost of the four module NOXSO Process as previously described is estimated at $\$ 115.4$ million or approximately $\$ 231 / \mathrm{kW}$. The total plant cost includes the following: land (approximately $65,000 \mathrm{ft}^{2}$ ), escalation during construction, initial catalyst charge, contingency, and all royalties and fees. Working capital was estimated at $3 \%$ of the total plant cost plus two months of the net operating costs. The startup expense and organization 
Table 3-8. Design Criteria for Economic Analysis

\begin{tabular}{|l|c|l|c|}
\hline Plant Size, MW & 500 & & \\
\hline Coal Firing Rate, tph & 198 & Sulfur in Coal, \% & 2.8 \\
\hline Coal Heating Value, Btu/lb & 12,000 & Flue Gas Oxygen Concentration, \% & 3.0 \\
\hline Net Heat Rate, Btu/kWh & 9,500 & Flue Gas $\mathrm{SO}_{2}$ Concentration, ppmd & 2,500 \\
\hline Capacity Factor, $\%$ & 90.0 & Flue Gas $\mathrm{NO}_{x}$ Concentration, ppmd & 600 \\
\hline
\end{tabular}

was estimated at $2 \%$ of the total plant cost. The total capital investment of $\$ 123.7$ million, or about $\$ 247 / \mathrm{kW}$, is the value on which the fixed capital charge will be applied to recover the capital investment.

Fixed and variable operating cost are also shown in Table 3-9. Due to the relative ease of operation, high reliability of the NOXSO Process, and process automation through the use of a distributed computer process control system, it is anticipated that the power plant will not need to employ additional staff to operate the NOXSO system. As such, the operating labor shown is based on $1 / 2$ of a skilled operator and $1 / 2$ of an unskilled operator per shift with the appropriate overhead and supervisory charges applied. Maintenance materials and labor is estimated at $\$ 1.2$ million per year. Maintenance requirements are based on pilot plant operating experience and accepted industry equipment maintenance requirements. The general and administrative expense was estimated at $2 \%$ of the total plant cost. The total plant fixed operating cost is $\$ 3.8$ million per year, or about $1 \mathrm{mill} / \mathrm{kWh}$.

The gross variable operating costs, $\$ 12.9$ million per year, or approximately 3.3 mills $/ \mathrm{kWh}$, were estimated at a $90 \%$ plant capacity factor and the unit rates shown. Including the revenue from the sale of elemental sulfur, $\$ 1.7$ million/year, the net operating and maintenance $(\mathrm{O} \& \mathrm{M})$ cost of the NOXSO system designed for a $500 \mathrm{MW}$ power plant burning $2.8 \%$ sulfur coal is $\$ 15.0$ million, or approximately 3.8 mills $/ \mathrm{kWh}$. 


\section{PLANT INFORMATION}

Power Plant Gross MW 500

Capacity Factor $\quad 0.90$

Number of NOXSO Modules 4

Heat Rate, BTU/kWh $\quad 9,500$

Coal Heating Value, BTU/lb $\quad 12,000$

Coal Sulfur, \% 2.80

NOx Loading, lb/mmBTU $\quad 0.80$

NOXSO PROCESS REMOVAL EFFICIENCIES

$\mathrm{SO} 2 \quad 98.0$

NOx $\quad 85.0$

EMISSIONS DATA, tpy

Uncontrolled SO2 $\quad 87,291$

Controlled SO2 $\quad 1,747$

Phase I SO2 Limit (2) $\quad 46,811$

Uncontrolled NOx $\quad 15,051$

Controlled NOx 2,262

CAPITAL COST, \$

Total Plant Cost (3) $\quad 115,400,000$

Working Capital (4) $\quad 5,963,000$

Startup Expense and Organization (5) $\quad 2,308,000$

Total Capital Investment $\quad \mathbf{1 2 3 , 6 7 1 , 0 0 0}$

$\$ \$ \mathbf{k W} \quad 247$

OPERATING AND MAINTENANCE COSTS

Economic Parameters

Electricity, \$/kWh $\quad 0.018$

Natural Gas, \$/mmBTU $\quad 2.50$

NOXSO Sorbent, $\$ / \mathrm{lb} \quad 1.50$

Water, $\$ / \mathrm{kgal} \quad 0.6$

Net Sulfur Value, \$/ton . $\quad 40$

Fixed Charge Rate, \% (6) 10.6

NOx Value, \$/ton (7) $\quad 800$

Fixed Operating Cost $\quad$ (\$/year)

Operating Labor (8)

Maintenance Materials \& Labor (9)

306,000

$1,191,000$

G \& A (5)

Total Fixed Operating Cost

$2,308,000$

$3,805,000$

$\underline{\text { (mills/kWh) }}$

0.08

0.30

0.59

Variable Operating Cost

Water

Claus Catalyst

112,000

74,000

$6,273,000$

Natural Gas

$5,296,000$

0.97

Sorbent

$1,161,000$

Net Electricity

Total Variable Operating Cost

$12,916,000$

0.03

0.02

1.59

1.34

0.29

GROSS OPERATING AND MAINTENANCE COST $\overline{16,721,000}$

3.28

SULFUR

$(1,714,000)$

4.24

(0.43)

NET OPERATING AND MAINTENANCE COST

$15,007,000$ 
Table 3-9. NOXSO Process Economic Analysis (1) continued

\title{
CONSTANT DOLLAR LEVELIZED COST WITH SULFUR PLANT REVENUE
}

\author{
$\$ / y r(10)$ \\ $28,116,000$ \\ mills/kWh \\ 7.1 \\ $\$ /$ ton SO2 with NOx Credit 209 \\ $\$$ /ton NOx $\quad 800$
}

\section{CONSTANT DOLLAR LEVELIZED COST WITH SULFUR PLANT AND SO2 EMISSION ALLOWANCE REVENUE}

Phase I Allowances

Phase I Emission Limit

46,811

SO2 Emissions with NOXSO

Excess Allowances Generated @ $\$ 300$

$\$ 13,519,000$

Net Levelized Cost

$\$ / y r(11)$

$14,597,000$

mills/kWh

3.7

$\$ /$ ton SO2 with NOx Credit

51

$\$ /$ ton NOx

800

(1) 1993 Dollars

(2) $2.5 \mathrm{lb} \mathrm{SO} 2 / \mathrm{mmBTU}$

(3) Includes the following: initial catalyst charge, engineering and home office fees, royalties, escalation during construction, contingency, G\&A, and constructor's fee.

(4) $3 \%$ of Total Plant Cost +2 months Net Operating Expenses.

(5) $2 \%$ of Total Plant Cost.

(6) Fixed Charge Rate based on 30 year book life, 20 year tax life, 38\% composite Federal and State tax, and $2 \%$ for property taxes and insurance.

(7) Conservative cost of NOx removal based on SCR technology.

(8) 1/2 skilled operator per shift, 1/2 unskilled operator per shift.

(9) Estimate based on pilot plant experience and expected life of equipment.

(10) Total Capital Investment $x$ Fixed Charge Rate + O\&M Costs - Sulfur Value.

(11) Total Capital Investment $x$ Fixed Charge Rate + O\&M Costs - Sulfur Value - SO2 Allowance 
A sensitivity analysis was performed to determine the effect of the net sale price of sulfur, the unit cost of natural gas and sorbent, and the energy credit on the net operating and maintenance cost. The results are shown in Figure 3-16. The baseline O\&M is 3.8 mills $/ \mathrm{kWh}$ and, as can be seen, large variations in the studied parameters do not significantly impact the net O\&M cost. If sulfur is disposed at a zero net profit the operating cost will only increase to $4.24 \mathrm{mills} / \mathrm{kWh}$. The price of natural gas can increase to $\$ 3.50 / \mathrm{mmBTU}$ producing a small increase in the net O\&M cost from the baseline of 3.81 to 4.44 mills $/ \mathrm{kWh}$. The O\&M cost will increase by 0.9 to 4.7 mills/kWh if the unit cost of the NOXSO sorbent increases by $\$ 1.00$ to $\$ 2.50 / 1 \mathrm{~b}$. If, assuming additional power can not be generated by the power plant due to integration with the NOXSO Process the net O\&M will increase from 3.81 to 4.14 mills $/ \mathrm{kWh}$. This assumes no credit was given for the resulting reduction in power plant coal feed rate.

On a constant 1993 dollar basis, i.e. no inflation applied to the variable operating costs, applying the fixed charge rate of $10.6 \%$ to the total capital investment and including the sulfur revenue, the levelized cost is $\$ 28.2$ million, or about $7.1 \mathrm{mills} / \mathrm{kWh}$. The fixed charge rate is an EPRI generated value based on a 30-year book life, 20 year tax life, and a $38 \%$ composite federal and state tax rate ${ }^{3}$. It also includes $2 \%$ for insurance. Neglecting the value of $\mathrm{NO}_{\mathrm{x}}$ removal, the levelized cost of the NOXSO system in terms of $\$ /$ ton $\mathrm{SO}_{2}$ removed would be very competitive at $\$ 329 /$ ton removed. However, the NOXSO system is an integrated process which simultaneously removes $\mathrm{SO}_{2}$ and $\mathrm{NO}_{\mathrm{x}}$ and thus it is impossible to separate the cost of removing the $\mathrm{SO}_{2}$ from the cost of removing $\mathrm{NO}_{x}$. Assigning a value of $\$ 800$ /ton of $\mathrm{NO}_{x}$ removed yields an $\mathrm{SO}_{2}$ removal cost of $\$ 209 /$ ton which is superior to current FGD costs of $\$ 350-600 /$ ton $^{4}$. The value of $\$ 800 /$ ton assigned to $\mathrm{NO}_{x}$ removal is based upon costs for high efficiency SCR processes. This is a conservative number, as SCR costs are typically higher. In addition, a range of cost effectiveness for $\mathrm{NO}_{x}$ control is cited at $\$ 570-\$ 1,500 /$ ton removed under several states Reasonably Available Control Technology (RACT) criteria.

It is also appropriate to consider over compliance since the high efficiency of the NOXSO Process will allow a utility to generate $\mathrm{SO}_{2}$ allowances which can be sold to partially offset the operating cost. The "Phase I SO $\mathrm{S}_{2}$ limit" in Table 3-9 is calculated based on allowable emissions of $2.5 \mathrm{Ib} \mathrm{SO}_{2} / \mathrm{mmBTU}$. Beginning with Phase II in the year 2000 the number of allowances generated will decrease; however, it is also likely that the value of allowances will increase significantly, offsetting to some degree the reduction in allowances generated. Based on the above assumptions, $\$ 13.5$ million would be generated by the sale of $\mathrm{SO}_{2}$ allowances offsetting the operating costs and reducing the levelized cost to $\$ 14.5$ million, or about 3.7 mills $/ \mathrm{kWh}$. The cost of $\mathrm{SO}_{2}$ removal with the credit for $\mathrm{NO}_{x}$ removal decreases to $\$ 51 /$ ton. Table 3-10 presents the utility and raw materials consumption for the four module NOXSO system based on the design criteria as given in Table 3-8.

\subsection{Plant Characterization}

Plant characterization activities are on hold until a new host site is identified. 
Figure 3-16. O \& M Sensitivity Analysis

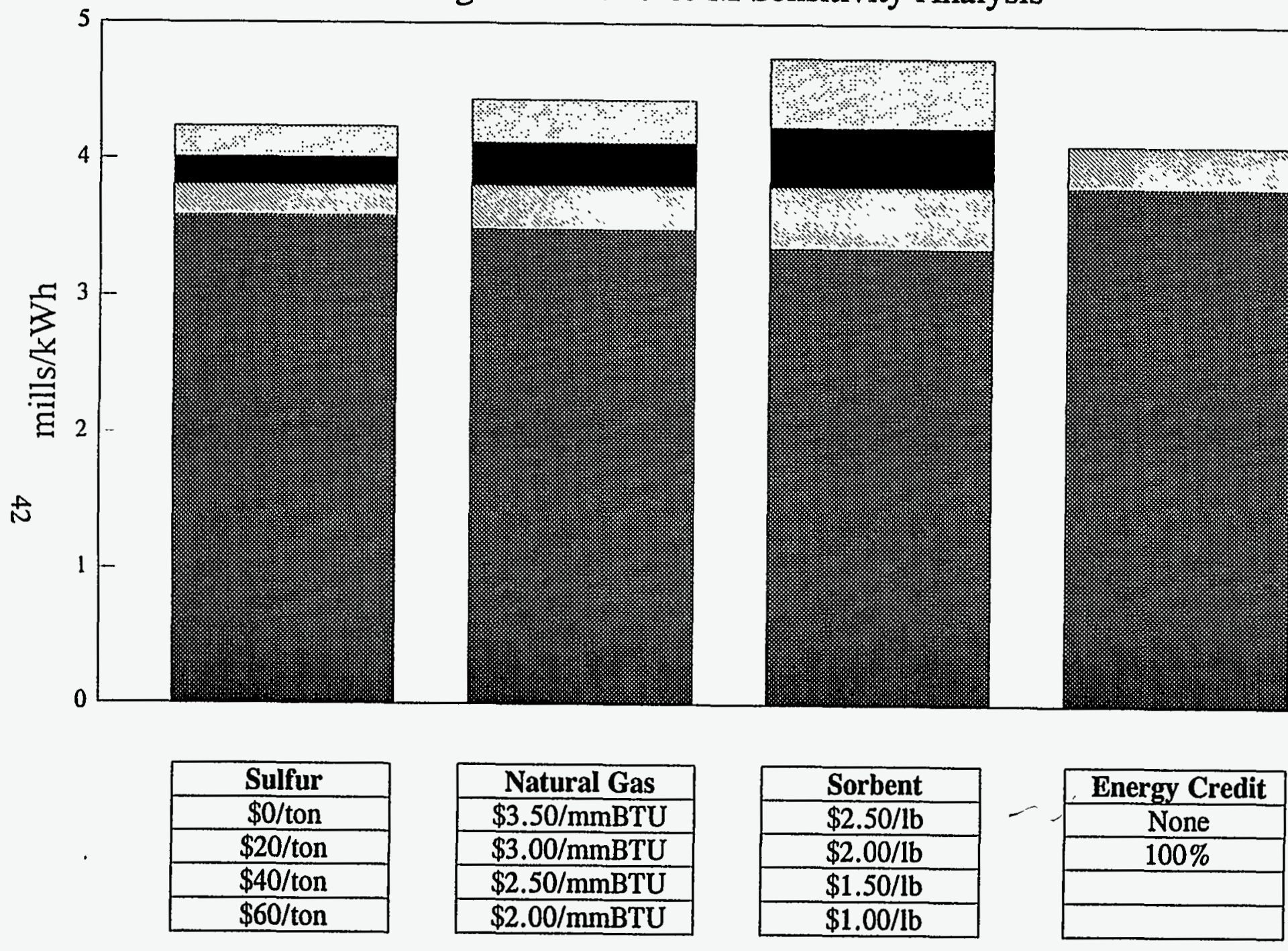


Table 3-10. Raw Material and Utility Consumption

NATURAL GAS, lb/hr

Air Heater

6,152

Regeneration

3,644

Sulfur Plant

Total Natural Gas

$\begin{array}{r}3,344 \\ \hline 13,140\end{array}$

SORBENT MAKEUP RATE, $\mathrm{lb} / \mathrm{hr}$

448

STEAM, lb/hr

Gross Claus Plant Steam Production

NOXSO Process Steam Consumption

Net Claus Plant Steam Production

WATER, gpm

ELECTRICAL POWER CONSUMPTION

Flue Gas Booster Fans

Sorbent Cooler/Heater Fans

Claus Plant

Air Compressors

Miscellaneous

Gross Electrical Power Consumption

Less Energy Credits

FD Fan Credit

NOx Recycle Credit

Claus Steam Credit

Combustion Air Steam Preheat Credit

Total Energy Credits

\begin{tabular}{rr}
387 & \multicolumn{2}{c}{$\begin{array}{c}\text { Gross Powe } \\
(\mathbf{\%})\end{array}$} \\
$\mathbf{( k W )}$ & 1.8 \\
2,748 & 0.5 \\
936 & 0.2 \\
3,104 & 0.6 \\
1,332 & 0.3 \\
\hline 16,944 & 3.4
\end{tabular}

Net Electrical Power Consumption

\begin{tabular}{rr}
200 & 0.0 \\
4,032 & 0.8 \\
3,446 & 0.7 \\
1,056 & 0.2 \\
\hline 8,734 & 1.7 \\
\cline { 2 - 2 } & \\
\hline \hline $\mathbf{8 , 2 1 0}$ & $\mathbf{1 . 7}$
\end{tabular}




\subsection{Site Survey/Geotechnical Investigation}

identified.

Site survey/geotechnical investigation activities are on hold until a new host site is

\subsection{Permitting}

Permitting activities are on hold until a new host site is identified.

\section{PLANS FOR NEXT QUARTER}

The main priority for next quarter is the evaluation and selection of a host site for the project. It is essential that a technically acceptable site be selected so the process can be properly demonstrated.

Immediately upon identification of the host site, work will begin to modify the EIV with information specific to the new site. It is critical to satisfy the NEPA requirements as soon as possible to prevent delaying the project.

The adsorber pressure vessel design procedure will be modified to be used for design of the high temperature, tapered sorbent heater and sorbent cooler vessels.

The need to perform additional $\mathrm{NO}_{x}$ destruction studies will be evaluated based on the boiler type for the new host site. If required, these studies could take the form of scaled experiments or computer modelling.

Demolition of the pilot plant will be completed this quarter. All equipment which can be reused at the commercial plant will be removed and placed in storage.

The fluid-bed adsorber computer model will be modified to allow analysis of multi-stage fluid-bed adsorbers. Using this model, the optimum number of adsorber stages will be determined. Additionally, work on the regenerator model will begin. Because the regeneration is much more complicated than adsorption, it is expected development of this model and conducting necessary laboratory experiments will require more time and effort than the adsorption model.

The NOXSO process simulation model will continue to be updated and developed to more accurately simulate the operation of the NOXSO process. A version of the simulation model will be developed to model off design cases. For example, how will various process parameters of a NOXSO process designed for flue gas containing $2500 \mathrm{ppm}$ of $\mathrm{SO}_{2}$ be affected when the system is operating on flue gas containing $1250 \mathrm{ppm}$ of $\mathrm{SO}_{2}$.

Tests will be conducted in the laboratory to determine the sorbent's capacity for adsorbing water at typical adsorber temperatures and flue gas water contents. 
As soon as a new host site is identified, activities to collect specific plant information, collect site and geotechnical information, and identify necessary permits will be initiated.

\section{REFERENCES}

1. Models for Flow Systems and Chemical Reactors, p.369, 1975.

2. "Reactant Dynamics in Catalytic Fluidized Bed Reactors with Flow Reversal of Gas in the Emulsion Phase", Chemical Engineering Science, vol. 37, no. 4, P.553, 1982.

3. Electronic Power Research Institute (EPRI) Study of Processes for Combined $\mathrm{SO}_{\mathrm{x}} / \mathrm{NO}_{\mathrm{x}}$ Control, 1990.

4. EPRI 1990 Update of FGD Economic Evaluations. 
APPENDIX I

ADSORBER GENERAL DATA 
JOB: DEMONSTRATION PLANT

ADSORBER

GENERAL DATA

INTERNAL

3.50 PSI

400.00 DEGF

0.125 IN RADIOGRAPHY:

NO

$3.00 \mathrm{FT}$
EXTERNAL

0.18 PSI

400.00 DEGF

SPOT

0.85

$35.00 \mathrm{LBM} / \mathrm{FT}^{\wedge} 3$

SORBENT : DEPTH

MATERIALS OF CONSTRUCTION

SHELL

TOP HEAD

BOTTOM HEAD

ROLLED NOZZLES

PIPE NOZZLES

FLANGES

STUD BOLTS

VACUUM STIFFENERS

SKIRT

\section{DESIGNATION}

SA-516 GR 70

SA-516 GR 70

SA-516 GR 70

SA-516 GR 70

$S A-106 B$

$S A-105$

SA-193 GR B7

SA-36

SA-36
ALLOWABLE STRESS

17500 PSI

17500 PSI

17500 PSI

17500 PSI

15000 PSI

17500 PSI

20000 PSI

14500 PSI

12700 PSI

258 IN

129 IN

LENGTH, TAN. TO TAN.

DIMENSIONAL DATA

\begin{tabular}{|c|c|c|}
\hline $516 \mathrm{IN}$ & RADIUS & $258 \mathrm{IN}$ \\
\hline $280 \mathrm{IN}$ & HEAD DEPTH & $129 \mathrm{IN}$ \\
\hline
\end{tabular}

\section{CALCULATIONS}

CYLINDRICAL SHELL

PARAGRAPH UG-27 THICKNESS OF SHELLS UNDER INTERNAL PRESSURE

CIRCUMFERENTIAL STRESS $-\mathrm{t}=\mathrm{P}^{*} \mathrm{R} /\left(\mathrm{S}^{*} E-0.6^{*} \mathrm{P}\right)=$

0.061 IN

PARAGRAPH UG-28 THICKNESS OF SHELLS UNDER EXTERNAL PRESSURE

\begin{tabular}{|c|c|c|c|}
\hline $\begin{array}{l}\text { Num } \\
\text { Dista }\end{array}$ & $\begin{array}{l}\text { dum stiffeners - } \\
\text { en lines of support - }\end{array}$ & $\begin{array}{r}= \\
L=\end{array}$ & $\begin{array}{c}0 \\
366 \text { IN }\end{array}$ \\
\hline Do/t= & 2040 & $L / D=$ & 0.709 \\
\hline$E=$ & 2.77E+07 PSI & & \\
\hline
\end{tabular}

FROM EQUATIONS ONLY - see "THEORY AND DESIGN OF PRESSURE VESSELS" by Harvey section 8.5 page 606 .

Required thickness for external pressure $-t=D^{*}\left(3^{*} L^{*} P a /\left(2.6^{*} D^{*} E\right)\right)^{\wedge} 0.4=\quad 0.253$ IN 
FROM EQUATIONS AND VACUUM CHARTS
$A=$
0.00000
$\mathrm{B}=$
0
ALLOWABLE EXTERNAL PRESSURE- $\mathrm{Pa}=4^{*} \mathrm{~B} /\left(3^{*} \mathrm{D} / \mathrm{t}\right)$
OR

ALLOWABLE EXTERNAL PRESSURE- $\mathrm{Pa}=2 * \mathrm{~A} * \mathrm{E} /\left(3^{*} \mathrm{D} / \mathrm{t}\right)$

$\begin{array}{ll}= & 0.000 \text { PSI } \\ = & 0.000 \text { PSI }\end{array}$

PARAGRAPH UG-29 STIFFENING RINGS FOR CYLINDRICAL SHELLS UNDER EXTERNAL PRESSURE

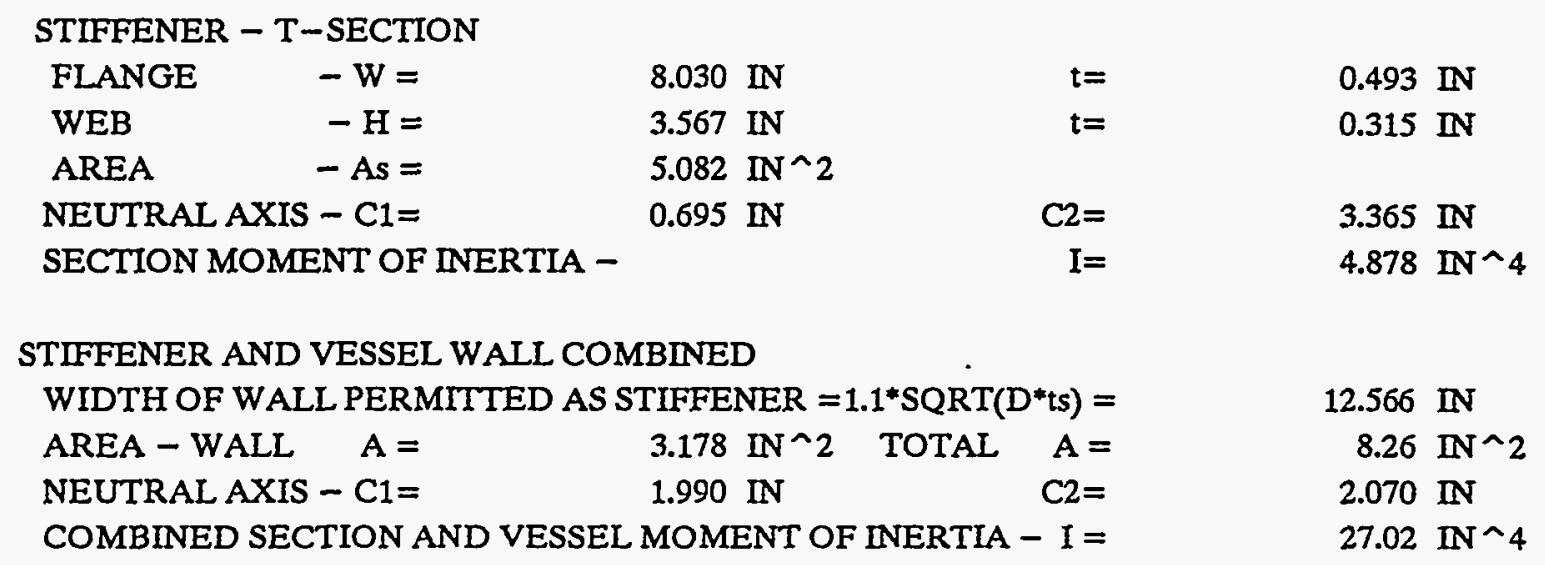

REQUIRED MOMENT OF INERTIA OF COMBINED SECTION AND VESSEL

$\begin{array}{lccc}B=0.75^{*} \mathrm{P}^{*} \mathrm{D} /(\mathrm{t}+\mathrm{As} / \mathrm{L})= & 5016 \quad \mathrm{~A}=2^{*} \mathrm{~B} / \mathrm{E}= & 0.00036 \\ \mathrm{REQ} & = & 44.97 \text { IN } \mathrm{N}^{\wedge} 4\end{array}$

\section{PARAGRAPH UG-23 MAXIMUM ALLOWABLE STRESS VALUES}

(b) Maximum allowable longitudinal compressive stress shall be the lesser of the allowable tensile stress or the value of $B$.

(d) For the combination of earthquake loading or wind loading with other loads the allowable stress found in (b) can be increased by $20 \%$.

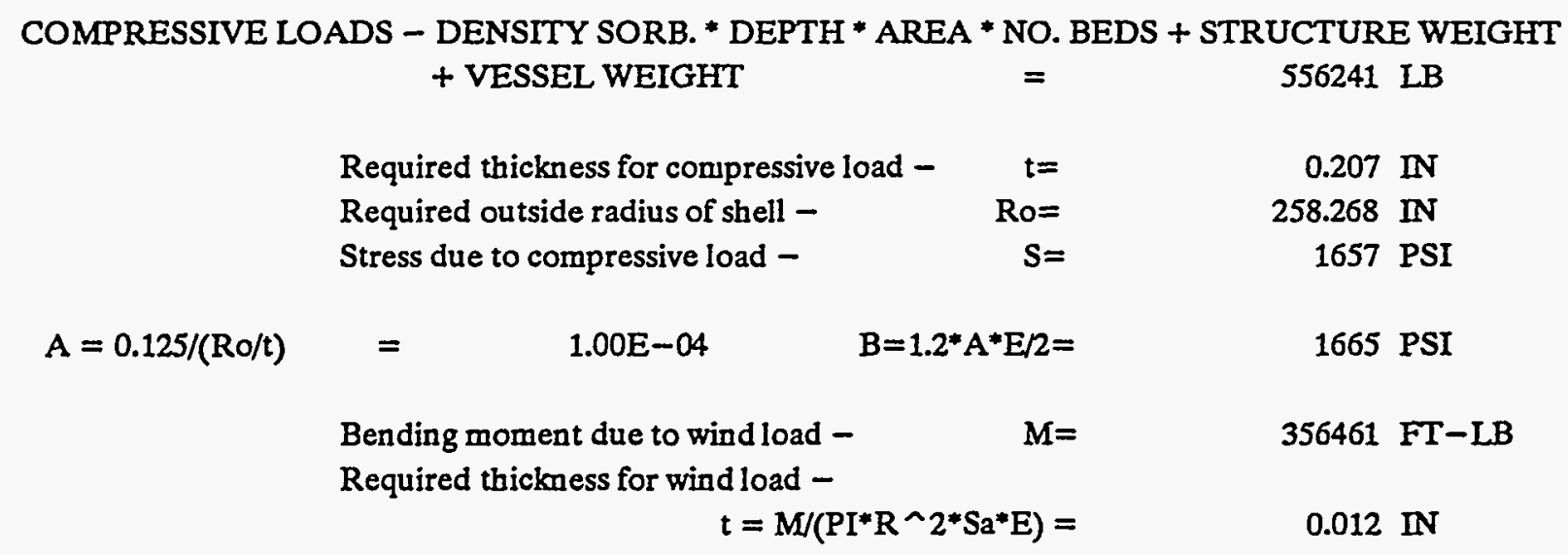


Bending moment due to earthquake load -

Required thickness for earthquake load -

$$
t=\mathrm{M} /(\mathrm{PI} * \mathrm{R} \wedge 2 * \mathrm{~s}
$$

Total required thickness for combined loads

Total required thickness for combined loads plus corrosion allowance

Actual thickness for combined loads plus corrosion allowance

Weight of cylindrical shell -
$\mathbf{M}=$
1041537 FT-LB

0.036 IN

$-t=$

0.496 IN

$0.621 \mathrm{IN}$

0.625 IN

79999 LB

\section{ELLIPSOIDAL HEADS}

TOP HEAD

PARAGRAPH UG-32 FORMED HEADS, AND SECTIONS, PRESSURE ON CONCAVE SIDE

(d) An acceptable approximation of a 2:1 ellipsodial head is knuckle radius $0.17^{*} \mathrm{D}$ and spherical radius $0.90 * D$.

$$
\mathrm{t}=\mathrm{P} * \mathrm{D} /(2 * \mathrm{~S} * \mathrm{E}-0.2 * \mathrm{P})=0.061 \mathrm{IN}
$$

PARAGRAPH UG -33 FORMED HEADS, AND SECTIONS, PRESSURE ON CONVEX SIDE

(d)

$$
\text { Required thickness for external pressure }-\quad t=\quad 0.061 \text { IN }
$$

\begin{tabular}{|c|c|c|}
\hline ALLOWABLE EXTERNAL PRESSURE $-\mathrm{Pa}=4^{*} \mathrm{~B} /\left(3^{*} \mathrm{Do} / \mathrm{t}\right)$ & $=$ & 0.000 PSI \\
\hline OR & & \\
\hline ALLOWABLE EXTERNAL PRESSURE $-\mathrm{Pa}=2^{*} \mathrm{~A}^{*} \mathrm{E} /\left(3^{*} \mathrm{Do} / \mathrm{t}\right)$ & $=$ & $0.266 \mathrm{PSI}$ \\
\hline
\end{tabular}

FROM EQUATIONS AND VACUUM CHARTS

$$
\mathrm{A}=0.125 /(\mathrm{Ro} / \mathrm{t})=0.00003 \quad \mathrm{~B}=\quad 0
$$

Minimum straight flange thickness $0.496 \mathrm{IN}$

$\begin{array}{lll}\text { Minimum straight flange thickness plus corrosion allowance- } & t= & 0.625 \text { IN }\end{array}$

Maximum formed section thin out 0.063 IN

Minimum required formed section thickness -

$\begin{array}{ll}t= & 0.063 \mathrm{IN} \\ \mathrm{t}= & 0.433 \mathrm{IN}\end{array}$

Minimum required formed section thickness plus corrosion allowance $-t=$ $0.563 \mathrm{IN}$

Weight of 2:1 elliptical top head -

$\mathrm{W}_{\text {th }}=$

66342 IB

\section{BOTTOM HEAD}

PARAGRAPH UG-32 FORMED HEADS, AND SECTIONS, PRESSURE ON CONCAVE SIDE

(d) An acceptable approximation of a 2:1 ellipsodial head is knuckle radius $0.17^{*} \mathrm{D}$ and spherical radius $0.90^{*} D$.

$$
\mathrm{t}=\mathrm{P}^{*} \mathrm{D} /\left(2^{*} \mathrm{~S}^{*} \mathrm{E}-0.2^{*} \mathrm{P}\right) \quad=\quad 0.061 \mathrm{IN}
$$




$$
\text { Required thickness for external pressure - } \quad t=\quad 0.061 \text { IN }
$$

FROM EQUATIONS AND VACUUM CHARTS
$A=0.125 /(\operatorname{Ro} / t) \quad=$
0.00003
$\mathrm{B}=$
0
ALLOWABLE EXTERNAL PRESSURE- $\mathrm{Pa}=4^{*} \mathrm{~B} /\left(3^{*} \mathrm{DO} / \mathrm{t}\right)$
OR
ALLOWABLE EXTERNAL PRESSURE-Pa $=2 * A * E /(3 * D o / t)$
$=$
0.000 PSI
$=\quad 0.266$ PSI

Minimum straight flange thickness -

Minimum straight flange thickness plus corrosion allowance-

Maximum formed section thinout -

$\mathrm{t}=$

0.496 IN

Minimum required formed section thickness -

$\mathrm{t}=$

0.625 IN

$0.063 \mathrm{IN}$

Minimum required formed section thickness plus corrosion allowance $-t=$ $0.433 \mathrm{IN}$

Minimum reguired formed section thickness pluscorrosion allowance $t=$

0.563 IN

Weight of 2:1 elliptical bottom head -

Wth $=$

66342 LB

FLUE GAS INLET NOZZLE

$\begin{array}{lrrr}\text { DIAMETER } & 120 \mathrm{IN} & \text { RADIUS } & 60 \mathrm{IN} \\ \text { LENGTH } & 12 \mathrm{IN} & & \end{array}$

PARAGRAPH UG-27 THICKNESS OF SHELLS UNDER INTERNAL PRESSURE

CIRCUMFERENTIAL STRESS $-\mathrm{t}=\mathrm{P}^{*} \mathrm{R} /\left(\mathrm{S}^{*} \mathrm{E}-0.6^{*} \mathrm{P}\right)=\quad 0.014 \mathrm{IN}$

PARAGRAPH UG-28 THICKNESS OF SHELLS UNDER EXTERNAL PRESSURE

$\begin{array}{rccc}\mathrm{Do} / \mathrm{t}= & 4467 & \mathrm{LD}= & 0.100 \\ \mathrm{E}= & 2.77 \mathrm{E}+07 \text { PSI } & \end{array}$

FROM EQUATIONS ONLY - see "THEORY AND DESIGN OF PRESSURE VESSELS" by Harvey section 8.5 page 606 .

Required thickness for external pressure $-t=D^{*}\left(3^{*} L^{*} P a /\left(2.6^{*} D^{*} E\right)\right)^{\wedge} 0.4=$

0.027 IN 
FROM EQUATIONS AND VACUUM CHARTS
$\mathrm{A}=$
0.00000
$\mathrm{B}=$
0

ALLOWABLE EXTERNAL PRESSURE- $\mathrm{Pa}=4^{*} \mathrm{~B} /\left(3^{*} \mathrm{D} / \mathrm{t}\right)$
OR

ALLOWABLE EXTERNAL PRESSURE-Pa $=2^{*} \mathrm{~A}^{*} \mathrm{E} /\left(3^{*} \mathrm{D} / \mathrm{t}\right) \quad=\quad 0.000$ PSI

Minimum nozzle thickness

- Minimum nozzle thickness plus corrosion allowance

$0.250 \mathrm{IN}$

$0.375 \mathrm{IN}$

FLUE GAS OUTLET NOZZLE

DIAMETER

LENGTH

120 IN RADIUS

12 IN

$t=$ 0.375 IN

PARAGRAPH UG-27 THICKNESS OF SHELIS UNDER INTERNAL PRESSURE

CIRCUMFERENTIALSTRESS $-\mathrm{t}=\mathrm{P}^{*} \mathrm{R} /\left(\mathrm{S}^{*} E-0.6^{*} \mathrm{P}\right)=\quad 0.014$ IN

PARAGRAPH UG-28 THICKNESS OF SHELLS UNDER EXTERNAL PRESSURE
Do/t $=$
4467
$\mathrm{L} / \mathrm{D}=$
0.100
$\mathrm{E}=$
2.77E+07 PSI

FROM EQUATIONS ONLY - see "THEORY AND DESIGN OF PRESSURE VESSELS" by Harvey section 8.5 page 606 .

Required thickness for external pressure $-t=D^{*}\left(3^{*} L^{*} P a /\left(2.6^{*} D^{*} E\right)\right)^{\wedge} 0.4=\quad 0.027$ IN

FROM EQUATIONS AND VACUUM CHARTS
$\mathbf{A}=$
0.00000
$\mathrm{B}=$
0

ALLOWABLE EXTERNAL PRESSURE- $\mathrm{Pa}=4^{*} \mathrm{~B} /\left(3^{*} \mathrm{D} / \mathrm{t}\right)$

$\begin{array}{ll}= & 0.000 \mathrm{PSI}\end{array}$

OR

ALLOWABLE EXTERNAL PRESSURE- $\mathrm{Pa}=2^{*} \mathrm{~A}^{*} \mathrm{E} /\left(3^{*} \mathrm{D} / \mathrm{t}\right) \quad=\quad 0.000$ PSI

Minimum nozzle thickness

Minimum nozzle thickness plus corrosion allowance

$\mathrm{t}=$

$0.250 \mathrm{IN}$

$t=$

$0.375 \mathrm{~N}$ 
PARAGRAPH UG-27 THICKNESS OF́ SHELLS UNDER INTERNAI PRESSURE

CIRCUMFERENTIAL STRESS $-\mathrm{t}=\mathrm{P}^{*} \mathrm{R} /\left(\mathrm{S}^{*} \mathrm{E}-0.6^{*} \mathrm{P}\right)=$ $0.003 \mathrm{IN}$

PARAGRAPH UG-28 THICKNESS OF SHELLS UNDER EXTERNAL PRESSURE

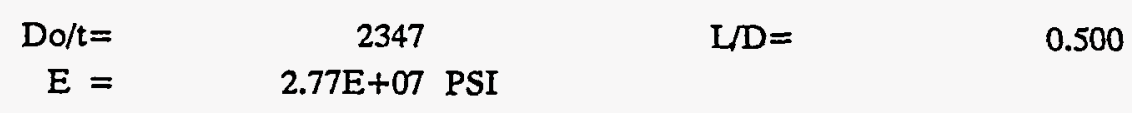

FROM EQUATIONS ONLY - see "THEORY AND DESIGN OF PRESSURE VESSELS" by Harvey section 8.5 page 606 .

Required thickness for external pressure $-t=D^{*}\left(3^{*} L^{*} P a /\left(2.6^{*} D^{*} E\right)\right)^{\wedge} 0.4=\quad 0.010$ IN

FROM EQUATIONS AND VACUUM CHARTS

$\mathrm{A}=\quad 0.00000 \quad \mathrm{~B}=\quad 0$

ALLOWABLE EXTERNAL PRESSURE-Pa $=4^{*} B /\left(3^{*} \mathrm{D} / \mathrm{t}\right) \quad=\quad 0.000$ PSI

OR

ALLOWABLE EXTERNAL PRESSURE- $\mathrm{Pa}=2 * \mathrm{~A} * \mathrm{E} /\left(3^{*} \mathrm{D} / \mathrm{t}\right) \quad=\quad 0.000$ PSI

Minimum nozzle thickness

$\mathrm{t}=\quad 0.375 \mathrm{IN}$

Minimum nozzle thickness plus corrosion allowance

$0.500 \mathrm{IN}$

\section{FLUE GAS INLET NOZZLE}

PARAGRAPH UG-37 REINFORCEMENT REQUIRED FOR OPENINGS IN SHELIS AND FORMED HEADS

For internal pressure tr and trn are the values required for the internal design pressure.

Required area

$$
\mathrm{A}=\mathrm{d}^{*} \operatorname{tr} * \mathrm{~F}+2^{*} \operatorname{tn} * \mathrm{tr}^{*} \mathrm{~F}^{*}(1-\mathrm{fr} 1) \quad=\quad 7.28 \mathrm{IN}^{\wedge} 2
$$

Area available in head; use larger value -

$$
\begin{aligned}
& A 1=d^{*}\left(E 1 * t-F^{*} \operatorname{tr}\right)-2 * \operatorname{tn}\left(E 1 * t-F^{*} t r\right)^{*}(1-f r 1) \quad=\quad 36.91 \mathrm{IN} \wedge 2 \\
& \text { or } \\
& A 1=2 *(t+t n) *\left(E 1 * t-F^{*} \operatorname{tr}\right)-2 * \operatorname{tn} *\left(E 1 * t-F^{*} t r\right)^{*}(1-f r 1)=\quad 0.420 \mathrm{NN} \text { ^2 }
\end{aligned}
$$

Area available in nozzle projecting outward; use smaller value -

$$
\begin{array}{rlr}
\mathrm{A} 2=5^{*}(\mathrm{tn}-\mathrm{tm}) * \mathrm{fr} 2 * \mathrm{t} & & \\
\text { or } & = & 0.511 \mathrm{IN} \wedge 2 \\
\mathrm{~A} 2=5^{*}(\mathrm{tn}-\mathrm{trn}) * \mathrm{fr} 2 * \mathrm{tn} & & 0.295 \mathrm{IN} \wedge 2 \\
\text { nozzle projecting inward } & = & 0.156 \mathrm{IN} \wedge 2 \\
\mathrm{~A} 3=2^{*}(\mathrm{tn}-\mathrm{c}) * \mathrm{fr} 2 * \mathrm{~h} & &
\end{array}
$$

Area available in nozzle projecting inward - 
Area available in nozzle projecting outward weld -

$$
A 41=(\mathrm{leg}) \wedge 2 * \mathrm{fr} 2
$$

Area available in nozzle projecting inward weld -

$$
\mathrm{A} 43=(\mathrm{leg}) \wedge 2 * \mathrm{fr} 2
$$

$=$

$0.063 \mathrm{IN} \leadsto 2$

Total area available for reinforcement -

$$
\mathrm{A} 1+\mathrm{A} 2+\mathrm{A} 3+\mathrm{A} 41+\mathrm{A} 43
$$

$=$

$37.49 \mathrm{IN} \wedge 2$

For external pressure tr and trn are the values required for the external design pressure.

Required area

$$
A=\left(d^{*} \operatorname{tr} * F+2 * \operatorname{tn} * \operatorname{tr} * F^{*}(1-f r 1)\right) / 2 \quad=\quad 3.64 \text { IN^2 }
$$

Area available in head; use larger value -

$$
\begin{aligned}
& A 1=d^{*}\left(E 1^{*} t-F^{*} \operatorname{tr}\right)-2^{*} \operatorname{tn} *\left(E 1^{*} t-F^{*} \operatorname{tr}\right)^{*}(1-\mathrm{fr} 1) \quad=\quad 36.91 \mathrm{IN} \wedge 2 \\
& A 1=2^{*}(t+t n) *\left(E 1 * t-F^{*} t r\right)-2 * t n^{*}\left(E 1^{*} t-F^{*} t r\right)^{*}(1-f r 1)=\quad 0.420 \text { IN`2 }
\end{aligned}
$$

Area available in nozzle projecting outward; use smaller value -

$$
\begin{aligned}
& \mathrm{A} 2=5^{*}(\mathrm{tn}-\mathrm{trn}) * \mathrm{fr} 2 * t \\
& =\quad 0.483 \mathrm{IN}^{\wedge} 2 \\
& \mathrm{~A} 2=5^{*}(\mathrm{tn}-\operatorname{trn}) * \mathrm{fr} 2 * \operatorname{tn} \quad=\quad 0.279 \mathrm{IN} \wedge 2 \\
& \mathrm{~A} 3=2 *(\mathrm{tn}-\mathrm{c}) * \mathrm{fr} 2 * \mathrm{~h} \quad=\quad 0.156 \mathrm{IN} \wedge 2 \\
& \mathrm{~A} 41=(\mathrm{leg}) \wedge 2 * \mathrm{fr} 2 \quad=\quad 0.063 \mathrm{IN} \wedge 2 \\
& \mathrm{~A} 43=(\mathrm{leg}) \wedge 2 * \mathrm{fr} 2 \quad=\quad 0.063 \mathrm{IN}^{\wedge} 2
\end{aligned}
$$

Area available in nozzle projecting inward -

Area available in nozzle projecting outward weld -

Area available in nozzle projecting inward weld -

Total area available for reinforcement -

$$
\mathrm{A} 1+\mathrm{A} 2+\mathrm{A} 3+\mathrm{A} 41+\mathrm{A} 43 \quad=\quad 37.47 \mathrm{IN}^{\wedge} 2
$$

PARAGRAPH UW-16 MINIMUM REQUIREMENTS FOR ATTACHMENT WELDS AT OPENINGS

(d) Neck Attached by Fillet or Partial Penetration Welds. Figure 16.1 (i).

Throat of welds $t 1$ and $t 2$ shall not be less than the smaller of $1 / 4^{n}$ or $.7 \mathrm{tmin}$. and $t 1+t 2$ must be greater than or equal to $1.25 \mathrm{tmin}$.

$\begin{array}{lll}\mathrm{tmin}=\text { lesser of } 3 / 4^{\prime \prime}, \mathrm{t} \text { or tn } & = & 0.250 \mathrm{IN} \\ \mathrm{t} 1=\mathrm{t} 2 & = & 0.175 \mathrm{IN} \\ 1.25^{*} \mathrm{tmin} & = & 0.313 \mathrm{IN} \\ \mathrm{t} 1+\mathrm{t} 2 & = & 0.350 \mathrm{IN} \\ \text { Minimum leg of weld } & = & 0.250 \mathrm{IN}\end{array}$

PARAGRAPH UG -41 STRENGTH OF REINFORCEMENT

(b)
(1) $\mathrm{W} 1-1=(\mathrm{A} 2+\mathrm{A} 41) * \mathrm{~S}$
$=$
$6254 \mathrm{LB}$
W $2-2=(A 2+A 3+A 41+A 43+2 * \operatorname{tn} * t * f r 1) * S=$
13873 LB
(2) $W=(A-(d-2 * t n) *(E 1 * t-F * t r))^{*} S=-515778 \mathrm{LB}$ 


\section{PARAGRAPH UW-15 WELDED CONNECTIONS}

(c) Allowable stress in shear for fillet weld =

Strength of connection elements:

$\begin{array}{llr}\text { Nozzle wall shear=PI/2*davg.*tn*Sa } & = & 578470 \mathrm{LB} \\ \text { Fillet weld shear=PI/2*dout. }{ }^{*} \operatorname{leg}^{*} \mathrm{Sa} & = & 405771 \mathrm{LB}\end{array}$

Strength paths:

$$
\begin{aligned}
& 1-1=\text { Nozzle wall shear }+ \text { Fillet weld shear }=\quad 984241 \text { LB } \\
& 2-2=\text { Inner+ Outer Fillet weld shear } \quad=\quad 811542 \text { LB }
\end{aligned}
$$

\section{FLUE GAS OUTLET NOZZLE}

\section{PARAGRAPH UG-37 REINFORCEMENT REQUIRED FOR OPENINGS IN SHELLS AND FORMED HEADS}

For internal pressure tr and trn are the values required for the internal design pressure.

Required area

$$
A=d^{*} \operatorname{tr} * F+2 * \operatorname{tn} * \operatorname{tr} F^{*}(1-f r 1) \quad=\quad 7.28 \mathrm{IN}^{\wedge} 2
$$

Area available in shell; use larger value -

$$
\begin{array}{rr}
A 1=d^{*}\left(E 1^{*} t-F^{*} t r\right)-2 * t n^{*}\left(E 1^{*} t-F^{*} t r\right) *(1-f r 1) & 36.91 \text { IN } 2 \\
\text { or } & = \\
A 1=2 *(t+t n)^{*}\left(E 1^{*} t-F^{*} t r\right)-2 * t n^{*}\left(E 1^{*} t-F^{*} t r\right)^{*}(1-f r 1)= & 0.420 \text { IN^2 }
\end{array}
$$

Area available in nozzle projecting outward; use smaller value -

$$
\begin{array}{r}
A 2=5^{*}(\operatorname{tn}-\operatorname{trn}) * \mathrm{fr} 2 * t \\
\text { or } \\
A 2=5^{*}(\operatorname{tn}-\operatorname{trn}) * \mathrm{fr} 2 * \operatorname{tn}
\end{array}
$$

Area available in nozzle projecting inward -

$$
A 3=2 *(t n-c) * f r 2 * h
$$

Area available in nozzle projecting outward weld -

$$
A 41=(\mathrm{leg}) \wedge 2 * \mathrm{fr} 2
$$

$$
\begin{array}{ll}
= & 0.295 \mathrm{IN}^{\wedge} 2 \\
= & 0.156 \mathrm{IN}^{\wedge} 2
\end{array}
$$

Area available in nozzle projecting inward weld -

$$
A 43=(\operatorname{leg})^{\wedge} 2 * \text { fr } 2
$$

$=$

$0.063 \mathrm{NN}^{\wedge} 2$

Total area available for reinforcement -

$$
\mathrm{A} 1+\mathrm{A} 2+\mathrm{A} 3+\mathrm{A} 41+\mathrm{A} 43
$$

$=$

$37.49 \mathrm{IN} \cap 2$

For external pressure tr and tm are the values required for the external design pressure.

Required area

$$
A=\left(d^{*} \operatorname{tr} * F+2 * \operatorname{tn} * t^{*} F^{*}(1-f r 1)\right) / 2
$$


Area available in shell; use larger value -

$$
\begin{aligned}
& \mathrm{A} 1=\mathrm{d}^{*}\left(\mathrm{E} 1^{*} \mathrm{t}-\mathrm{F}^{*} \mathrm{tr}\right)-2^{*} \operatorname{tn}{ }^{*}\left(\mathrm{E} 1^{*} \mathrm{t}-\mathrm{F}^{*} \mathrm{tr}\right) *(1-\mathrm{fr} 1) \quad=\quad 36.91 \mathrm{IN} \wedge 2 \\
& A 1=2^{*}(t+t n)^{*}\left(E 1^{*} t-F^{*} t r\right)-2 * t n^{*}\left(E 1^{*} t-F^{*} t r\right)^{*}(1-f r 1)=\quad 0.420 \text { IN^2 }
\end{aligned}
$$

Area available in nozzle projecting outward: use smaller value -

$$
\begin{array}{lll}
\mathrm{A} 2=5^{*}(\mathrm{tn}-\mathrm{tm}) * \mathrm{fr} 2 * \mathrm{t} & = & 0.483 \mathrm{IN} \wedge 2 . \\
\text { or } & = & 0.279 \mathrm{IN} \bumpeq 2 .
\end{array}
$$

Area available in nozzle projecting inward -

$$
\mathrm{A} .3=2 *(\mathrm{tn}-\mathrm{c}) * \mathrm{fr} 2 * \mathrm{~h}
$$

Area available in nozzle projecting outward weld -

$$
A 41=(\operatorname{leg}) \wedge 2 * f r 2
$$

$=$

$0.156 \mathbb{N} \wedge 2$

Area available in nozzle projecting inward weld -

$$
\mathrm{A} 43=(\mathrm{leg}) \wedge 2 * \mathrm{fr} 2
$$

$=$

$0.063 \mathrm{IN} \sim 2$

$=$

$0.063 \mathrm{NN}^{\wedge} 2$

Total area available for reinforcement -

$$
\mathrm{A} 1+\mathrm{A} 2+\mathrm{A} 3+\mathrm{A} 41+\mathrm{A} 43
$$

$=\quad 37.47 \mathrm{IN} \wedge 2$

PARAGRAPH UW-16 MINIMUM REQUIREMENTS FOR ATTACHMENT WELDS AT OPENTNGS (d) Neck Attached by Fillet or Partial Penetration Welds. Figure 16.1 (i).

Throat of welds $t 1$ and $t 2$ shall not be less than the smaller of $1 / 4^{n}$ or $.7 \mathrm{tmin}$. and $t 1+t 2$ must be greater than or equal to $1.25 \mathrm{tmin}$.

$\begin{array}{lll}\mathrm{tmin}=\text { lesser of } 3 / 4^{\mathrm{n}}, \mathrm{t} \text { or } \mathrm{tn} & = & 0.250 \mathrm{IN} \\ \mathrm{t} 1=\mathrm{t} 2 & = & 0.175 \mathrm{IN} \\ 1.25^{*} \mathrm{tmin} & = & 0.313 \mathrm{IN} \\ \mathrm{t} 1+\mathrm{t} 2 & = & 0.350 \mathrm{IN} \\ \text { Minimum leg of weld } & = & 0.250 \mathrm{IN}\end{array}$

PARAGRAPH UG-41 STRENGTH OF REINFORCEMENT

(b)
(1) $\mathrm{W} 1-1=(\mathrm{A} 2+\mathrm{A} 41)^{*} \mathrm{~S}$
$=$
6254 LB
$\mathrm{W} \cdot 2-2=(\mathrm{A} 2+\mathrm{A} 3+\mathrm{A} 41+\mathrm{A} 43+2 * \operatorname{tn} * t * \mathrm{fr} 1) * \mathrm{~S}=$
13873 LB
(2) $W=\left(A-(d-2 * \operatorname{tn}) *\left(E 1 * t-F^{*} t r\right)\right)^{*} S=$
$-515778 \mathrm{LB}$

\section{PARAGRAPH UG-45 NOZZLE NECK THICKNESS}

(c) Allowable stress in shear for nozzle neck $=12250$ PSI

\section{PARAGRAPH UW-15 WELDED CONNECTIONS}

(c) Allowable stress in shear for fillet weld $=8575$ PSI

Strength of connection elements:

$\begin{array}{llr}\text { Nozzle wall shear }=P I / 2 * \text { davg. }{ }^{*} \text { tn }{ }^{* S a} & = & 578470 \mathrm{LB} \\ \text { Fillet weld shear }=P I / 2 * \text { dout.* }{ }^{*} \text { eg }^{*} \mathrm{Sa} & = & 405771 \mathrm{LB}\end{array}$


Strength paths:

$$
\begin{aligned}
& 1-1=\text { Nozzle wall shear }+ \text { Fillet weld shear }=984241 \mathrm{LB} \\
& 2-2=\text { Inner+ Outer Fillet weld shear } \quad=\quad 811542 \mathrm{LB}
\end{aligned}
$$

\section{MANWAYS}

PARAGRAPH UG-37 REINFORCEMENT REQUIRED FOR OPENINGS IN SHELLS AND FORMED HEADS

For internal pressure tr and $t m$ are the values required for the internal design pressure.

Reinforcing element to be made from shell plate.

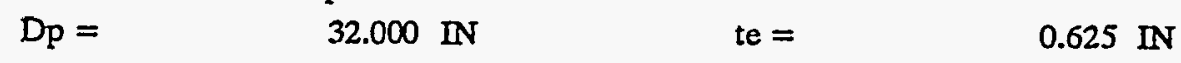

Required area

$$
A=d^{*} \operatorname{tr} * F+2 * \operatorname{tn} * t^{*} F^{*}(1-f r 1) \quad=\quad 1.46 \mathrm{IN}^{\wedge} 2
$$

Area available in shell; use larger value -

$$
\begin{aligned}
& \mathrm{A} 1=\mathrm{d}^{*}\left(\mathrm{E} 1^{*} \mathrm{t}-\mathrm{F}^{*} \mathrm{tr}\right)-2^{*} \operatorname{tn}{ }^{*}\left(\mathrm{E} 1^{*} \mathrm{t}-\mathrm{F}^{*} \mathrm{tr}\right) *(1-\mathrm{fr} 1) \quad=\quad 8.66 \mathrm{IN}^{\wedge} 2 \\
& A 1=2 *(t+t n) *\left(E 1 * t-F^{*} \operatorname{tr}\right)-2 * \operatorname{tn} *(E 1 * t-F * t r) *(1-f r 1)=\quad 0.628 \mathrm{IN} \wedge 2
\end{aligned}
$$

Area available in nozzle projecting outward; use smaller value -

$$
\begin{array}{lll}
\mathrm{A} 2=5 *(\operatorname{tn}-\mathrm{tm}) * \mathrm{fr} 2 * \mathrm{t} & = & 0.895 \mathrm{IN} \sim 2 \\
\text { or } & & \\
\mathrm{A} 2=2 *(\mathrm{tn}-\mathrm{tm}) * \mathrm{fr} 2 *(\mathrm{tn}+\mathrm{te}) & 0.722 \mathbb{I N} \wedge 2
\end{array}
$$

Area available in nozzle projecting inward - ,

$$
A 3=2 *(\operatorname{tn}-c) * f r 2 * h
$$

Area available in nozzle projecting outward weld -

$$
A 41=(\operatorname{leg})^{\wedge} 2 * \text { fr } 2
$$

$=$

$=$

$=$

$=$

$$
A 5=(D p-d-2 * \text { tn }) t e * f r 4
$$

Total area available for reinforcement -

$$
\mathrm{A} 1+\mathrm{A} 2+\mathrm{A} 3+\mathrm{A} 41+\mathrm{A} 43+\mathrm{A} 5
$$

$=$

15.17 IN $\wedge 2$

For external pressure tr and tm are the values required for the external design pressure.

Required area

$$
A=\left(d^{*} \operatorname{tr} * F+2^{*} \operatorname{tn} * \operatorname{tr}^{*} F^{*}(1-f r 1)\right) / 2
$$

$=$

5.95 INA2

Area available in shell; use larger value -

$$
\begin{aligned}
& A 1=d^{*}\left(E 1 * t-F^{*} t r\right)-2^{*} \operatorname{tn} *\left(E 1 * t-F^{*} t r\right) *(1-f r 1)= \\
& \text { or } \\
& A 1=2 *(t+t n) *\left(E 1 * t-F^{*} t r\right)-2 * \operatorname{tn} *\left(E 1 * t-F^{*} t r\right) *(1-f r 1)=
\end{aligned}
$$


Area available in nozzle projecting outward; use smaller value -

$$
\begin{array}{lll}
\mathrm{A} 2=5^{*}(\mathrm{tn}-\mathrm{tmn}) & = & \mathrm{fr} 2 * \mathrm{t} \\
\text { or } & & 0.904 \mathrm{IN} \wedge 2 \\
\mathrm{~A} 2=2 *(\mathrm{tn}-\mathrm{tmn}) * \mathrm{fr} 2 *(\mathrm{tn}+\mathrm{te}) & & 0.730 \mathrm{IN} \wedge 2
\end{array}
$$

Area available in nozzle projecting inward -

$$
\mathrm{A} .3=2^{*}(\operatorname{tn}-\mathrm{c}) * \mathrm{fr} 2^{*} \mathrm{~h}
$$

$=$

$0.469 \mathrm{IN} \wedge 2$

Area available in nozzle projecting outward weld -

$$
\mathrm{A} 41=(\mathrm{leg}) \wedge 2 * \mathrm{fr} 2
$$

$=$

$\stackrel{=}{=}$

$=$

$=$

\section{$0.128 \mathrm{IN} \wedge 2$}

$0.072 \mathrm{IN}^{\wedge} 2$

$0.141 \mathbb{N N}^{\wedge} 2$

$5.000 \mathrm{IN}^{\wedge} 2$

$6.54 \mathrm{IN} \wedge 2$

PARAGRAPH UW-16 MINIMUM REQUIREMENTS FOR ATTACHMENT WELDS AT OPENINGS

(d) Neck Attached by Fillet or Partial Penetration Welds. Figure 16.1 (s).

Throat of weld tc shall not be less than the smaller of $1 / 4^{n}$ or $.7 \mathrm{tmin}$.

Throat of weld tw shall not be less than $.7 \mathrm{tmin}$.

Throat of reinforcing element outer weld shall not be less than $.5 \mathrm{tmin}$.

$\begin{array}{lll}\mathrm{tmin}=\text { lesser of } 3 / 4 ", \mathrm{t} \text { or } \mathrm{tn} & = & 0.375 \mathrm{IN} \\ \mathrm{tc} & = & 0.250 \mathrm{IN} \\ \mathrm{tw} & = & 0.263 \mathrm{IN} \\ \text { Throat of reinforcing element outer weld } & = & 0.188 \mathrm{IN} \\ \text { Minimum leg of weld tc } & = & 0.357 \mathrm{IN} \\ \text { Minimum leg of weld tw } & = & 0.375 \mathrm{IN} \\ \text { Leg of reinforcing element outer weld } & = & 0.268 \mathrm{IN}\end{array}$

PARAGRAPH UG-41 STRENGTH OF REINFORCEMENT

(b)

(1) $\mathrm{W} 1-1=(\mathrm{A} 2+\mathrm{A} 41) * \mathrm{~S}$

$=$

$\mathrm{W} 2-2=\left(\mathrm{A} 2+\mathrm{A} 3+\mathrm{A} 41+\mathrm{A} 43+2 * \operatorname{tn} * \mathrm{t}^{*} \mathrm{fr} 1\right) * \mathrm{~S}$

$=$

W $3-3=\left(\mathrm{A} 2+\mathrm{A} 3+\mathrm{A} 5+\mathrm{A} 41+\mathrm{A} 42+\mathrm{A} 43+2 * \operatorname{tm}{ }^{*} \mathrm{t}^{*} \mathrm{fr} 1\right) * \mathrm{~S}=$

(2) $W=\left(A-(d-2 * t n)^{*}\left(E 1 * t-F^{*} t r\right)\right) * S$
14863 LB

$25298 \mathrm{LB}$

114054 LB

$25500 \mathrm{LB}$

\section{PARAGRAPH UG-45 NOZZLE NECK THICKNESS}

(c) Allowable stress in shear for nozzle neck =

12250 PSI 
PARAGRAPH UW-15 WELDED CONNECTIONS

(c) Allowable stress in welds:

Shear in outward nozzle fillet

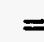

Shear in inward nozzle fillet

Shear in outer element fillet

Tension in element groove weld

$=$

$=$
$=$

$\Rightarrow$

Nozzle wall shear $=P I / 2 *$ davg. $*$ tn $* S a$

Inward fillet weld shear=PI/2*dout. ${ }^{*} \operatorname{leg}^{*} \mathrm{Sa}=$ Outward fillet weld shear=PI/2*dout. ${ }^{*} \operatorname{leg} * \mathrm{Sa}=$ Element fillet weld shear $=P I / 2 * D p * l e g * S a=$ Element grve. weld tension $=\mathrm{PI} / 2 *$ dout. $* t e^{*} \mathrm{Sa}=$

8575 PSI
8575 PSI
8575 PSI
12950 PSI

Strength of connection elements:

$\begin{array}{lll}\text { Nozzle wall shear=PI/2*davg.*tn*Sa } & = & 170474 \mathrm{LB} \\ \text { Inward fillet weld shear }=\mathrm{PI} / 2 * \text { dout. }{ }^{*} \mathrm{leg}^{*} \mathrm{Sa} & = & 121226 \mathrm{LB} \\ \text { Outward fillet weld shear=PI/2*dout. }{ }^{*} \mathrm{leg}^{*} \mathrm{Sa} & = & 115454 \mathrm{LB} \\ \text { Element fillet weld shear=PI/2*Dp*leg*Sa }= & 174358 \mathrm{LB} \\ \text { Element grve. weld tension=PI/2*dout.*te*Sa }= & 305127 \mathrm{LB}\end{array}$

Strength paths:

$1-1=$ Nozzle wall shear + Element fillet weld shear

$=$

344833 LB

$2-2=$ Inward + Outward fillet weld shear + Element groove weld tension $=$

541807 LB

$3-3=$ Inward fillet weld shear + Element fillet weld shear

$=$

295585 LB

\section{SUPPORT SKIRT}

Per Appendix G paragraph 5 (b) the mean diameter of the skirt is to coincide with the mean diameter of the shell to to minimize local stresses. The height of the skirt (height of the bottom tangent line) is to be two inlet nozzle diameters plus the depth of a head.
Dmskirt $=$
516.496 IN
Height $=$
369 IN
Dmskirt $=$
$43.0 \mathrm{FT}$.
Height $=$
30.8 FT

\section{PARAGRAPH UG-23 MAXIMUM ALLOWABLE STRESS VALUES}

(b) Maximum allowable longitudinal compressive stress shall be the lesser of the allowable tensile stress or the value of $B$.

(d) For the combination of earthquake loading or wind loading with other loads the allowable stress found in (b) can be increased by $20 \%$.

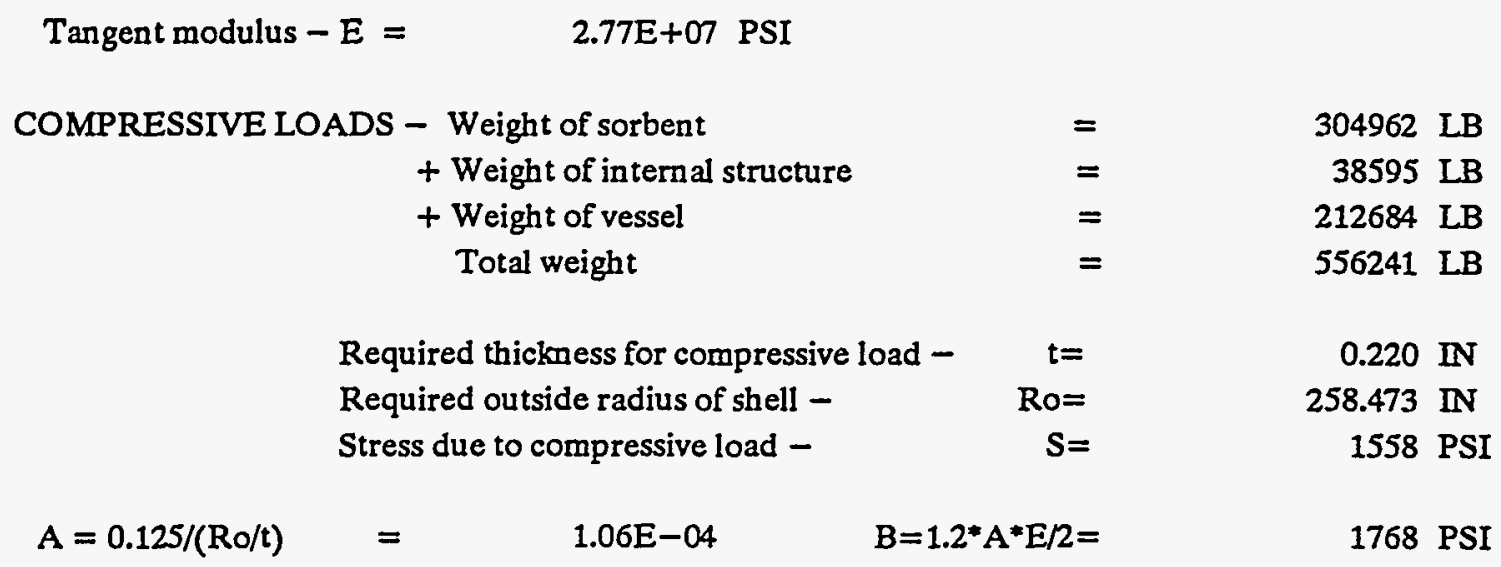


Bending moment due to wind load - $\quad M=$ Required thickness for wind load -

$$
t=M /(P I * R \wedge 2 * S a * E)=
$$

Bending moment due to earthquake load - $\quad M=$ Required thickness for earthquake load -

$$
t=M /\left(P I * R^{\wedge} 2 * S a * E\right)=
$$

Total required thickness for combined loads -

$t=$

$t=$

$t=$

Actual thickness of skirt plus corrosion allowance -
356461 FT-LB

$0.012 \mathrm{IN}$

1041537 FT-LB

$0.034 \mathrm{IN}$

0.254 IN

$0.375 \mathrm{IN}$

$0.500 \mathrm{IN}$

\section{PARAGRAPH UG-37 REINFORCEMENT REQUIRED FOR OPENINGS IN SHELLS AND FORMED HEADS}

Opening required for the flue gas inlet duct, duct diameter +12 inches $=$

$132.00 \mathrm{IN}$

Reinforcing element to be made from skirt plate. Use element inside and outside.

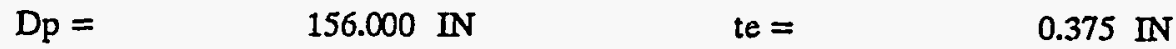

Required area

$$
A=\left(d^{*} \operatorname{tr} * F+2 * \operatorname{tn} * \operatorname{tr} F^{*}(1-f r 1)\right) / 2 \quad=\quad 16.75 \mathrm{IN}^{\wedge} 2
$$

Area available in shell; use larger value -

$$
\begin{array}{ll}
A 1=d^{*}\left(E 1^{*} t-F^{*} t r\right)-2^{*} \operatorname{tn}\left(E 1^{*} t-F^{*} t r\right) *(1-f r 1) & 15.998 \mathrm{IN}^{\wedge} 2 \\
\text { or } & =
\end{array}
$$

Area available in nozzle projecting outward; use smaller value -

$$
A 2=2 *(\operatorname{tn}-c) * \text { fr } 2 * h
$$

$=$

Area available in nozzle projecting inward -

$$
A .3=2 *(\operatorname{tn}-c) * \mathrm{fr} 2 * h
$$

Area available in nozzle projecting outward weld -

$$
A 41=(\operatorname{leg})^{\wedge} 2 * \mathrm{fr} 2
$$

Area available in outer weld -

$$
A 42=2 *(\operatorname{leg}) \wedge 2 * \mathrm{fr} 2
$$

Area available in nozzle projecting inward weld -

$$
A 43=(\operatorname{leg})^{\wedge} 2 * \mathrm{fr} 2
$$

Area available in element -

$$
A 5=2 *(D p-d) * t e * f r 4
$$

Total area available for reinforcement -

$$
\mathrm{A} 1+\mathrm{A} 2+\mathrm{A} 3+\mathrm{A} 41+\mathrm{A} 43+\mathrm{A} 5
$$

Weight of skirt -$$
=
$$$$
=
$$$$
=
$$$$
=
$$$$
=
$$$$
0.469 \mathrm{~N}^{\wedge} 2
$$$$
0.469 \mathrm{~N}^{\wedge} 2
$$$$
0.128 \mathrm{IN}^{\wedge} 2
$$$$
0.143 \mathrm{IN}^{\wedge} 2
$$$$
0.141 \mathrm{~N} \sim 2
$$$$
18.000 \mathrm{IN}^{\wedge} 2
$$$$
=
$$$$
35.35 \mathrm{IN}^{\wedge} 2
$$$$
=
$$$$
88385 \text { LB }
$$ 


\begin{tabular}{|c|c|c|c|c|}
\hline \multicolumn{5}{|l|}{ Base plate: } \\
\hline Width & $=$ & $8.000 \mathrm{IN}$ & Thickness & $1.000 \mathrm{IN}$ \\
\hline Bearing load & $=$ & 99 PSI & & \\
\hline Bolt circle & $=$ & 523.996 IN & Bolt diameter = & $1.000 \mathrm{IN}$ \\
\hline Number of bolts & $=$ & 27 & Chord length $=$ & $60.832 \mathrm{IN}$ \\
\hline
\end{tabular}


MATERIALS OF CONSTRUCTION DESIGNATION

$\begin{array}{lr}\text { BEAMS } & \text { SA-36 } \\ \text { SUPPORT CHAIRS } & \text { SA-36 }\end{array}$

MODULUS - $\quad E=2.77 E+07$ PSI

NO. OF MAIN BEAMS $=4$ SPACINGCTOC $\quad$ = 8.600 FT

BEAM LOADING - $\quad w=\quad 903 \mathrm{LB} / \mathrm{FT}$

FIRST BEAM OFF VESSEL CENTER LINE -

\begin{tabular}{|c|c|c|c|c|}
\hline LENGTH - $\quad L=$ & \multicolumn{2}{|l|}{$42.131 \mathrm{FT}$} & & \\
\hline \multicolumn{3}{|c|}{ MAXIMUM BENDING MOMENT $-\mathrm{Mmax}=w^{*} \mathrm{~L} \wedge 2 / 8$} & 200358 & $F T-I B$ \\
\hline \multicolumn{3}{|c|}{ MINIMUM SECTION MODULUS - Zmin = Mmax/Sa } & 165.8 & $\mathbb{I N}^{\wedge} \mathbf{3}$ \\
\hline \multicolumn{3}{|c|}{ MAXIMUM SHEAR LOAD - Vmax $=w^{*} L / 2$} & 19022 & LB \\
\hline \multicolumn{5}{|l|}{ BEAM 27 WF $94-27^{n} \times 10^{n}$} \\
\hline WEB AREA - $\quad$ Aw $=$ & $12.454 \mathrm{IN}^{\wedge} 2$ & WEIGHT & 94 & LB/ET \\
\hline MMNT. OF INERTIA - I = & $3266.7 \mathrm{IN}^{\wedge} 4$ & SECTION MODULUS $-\mathbf{Z}=$ & 242.8 & $\mathrm{IN}^{\wedge} \mathbf{3}$ \\
\hline \multicolumn{3}{|c|}{ BENDING STRESS $-\mathrm{Sb}=\mathrm{Mmax} / \mathrm{Z}$} & 9902 & PSI \\
\hline \multicolumn{3}{|c|}{ MAXIMUM SHEAR STRESS - Ss = Vmax/Aw } & 1527 & PSI \\
\hline \multicolumn{3}{|c|}{ MAXIMUM DEFLECTION - ymax $=5^{*} w^{*} L^{\wedge} 4 /\left(384^{*} E^{*} I\right)$} & 0.707 & IN \\
\hline \multicolumn{3}{|l|}{ WEIGHT OF BEAM } & 3960 & IB/BEA \\
\hline
\end{tabular}

SECOND BEAM OFF VESSEL CENTER LINE -

LENGTH - $\quad$ L $=\quad 34.400 \mathrm{FT}$

MAXIMUM BENDING MOMENT $-\mathrm{Mmax}=\mathrm{w}^{*} \mathrm{~L} \wedge 2 / 8$

MINIMUM SECTION MODULUS $-\mathrm{Zmin}=\mathrm{Mmax} / \mathrm{Sa}$

MAXIMUM SHEAR LOAD - Vmax $=w^{*} L / 2$

$=133572$ FT-LB

$=\quad 110.5 \mathrm{IN}^{\wedge} 3$

$=15532 \mathrm{LB}$

BEAM 24 WF $76-24^{\prime \prime} \times 9^{\prime \prime}$

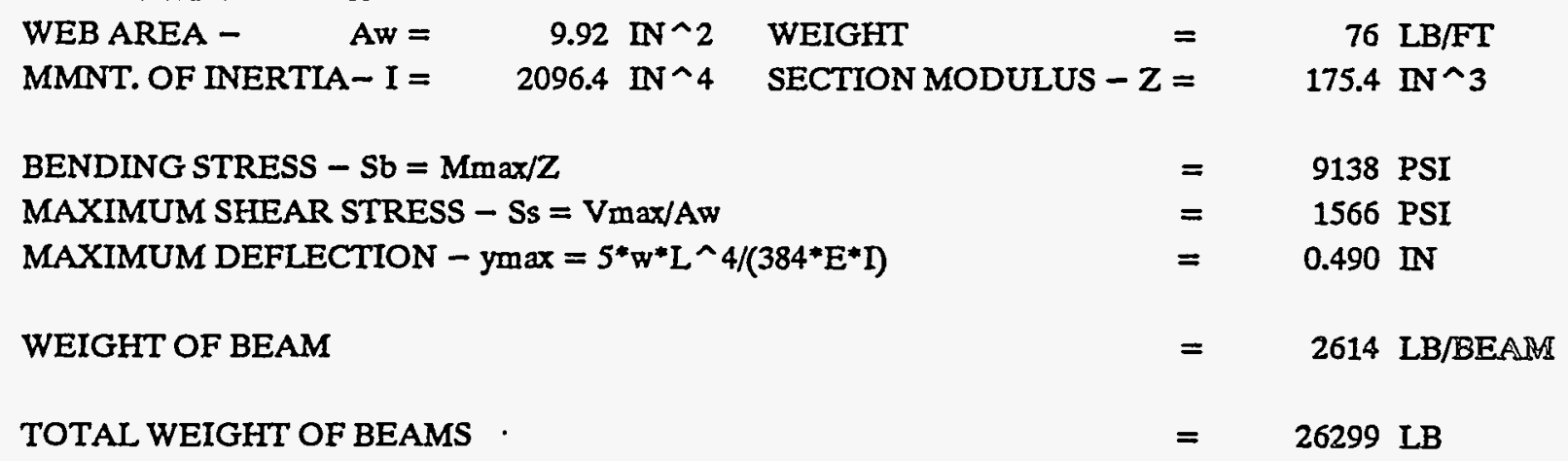




\section{DISTRIBUTOR GRID PLATES}

MATERIALS OF CONSTRUCTION

GRID PLATES

MODULUS -

\section{DESIGNATION}

SA-240 TYPE 316

$\mathrm{E}=2.59 \mathrm{E}+07$ PSI
AILOWABLE STRESS

18100 PSI
PLATE WIDTH

LOWER FLANGE WIDTH
20 IN

2 IN
DIMENSIONAL DATA

WEB HEIGHT

THICKNESS
$6 \mathrm{IN}$

$0.105 \mathrm{IN}$

MOMENT OF INERTIA BY THE PARALIEL AXIS THEOREM -

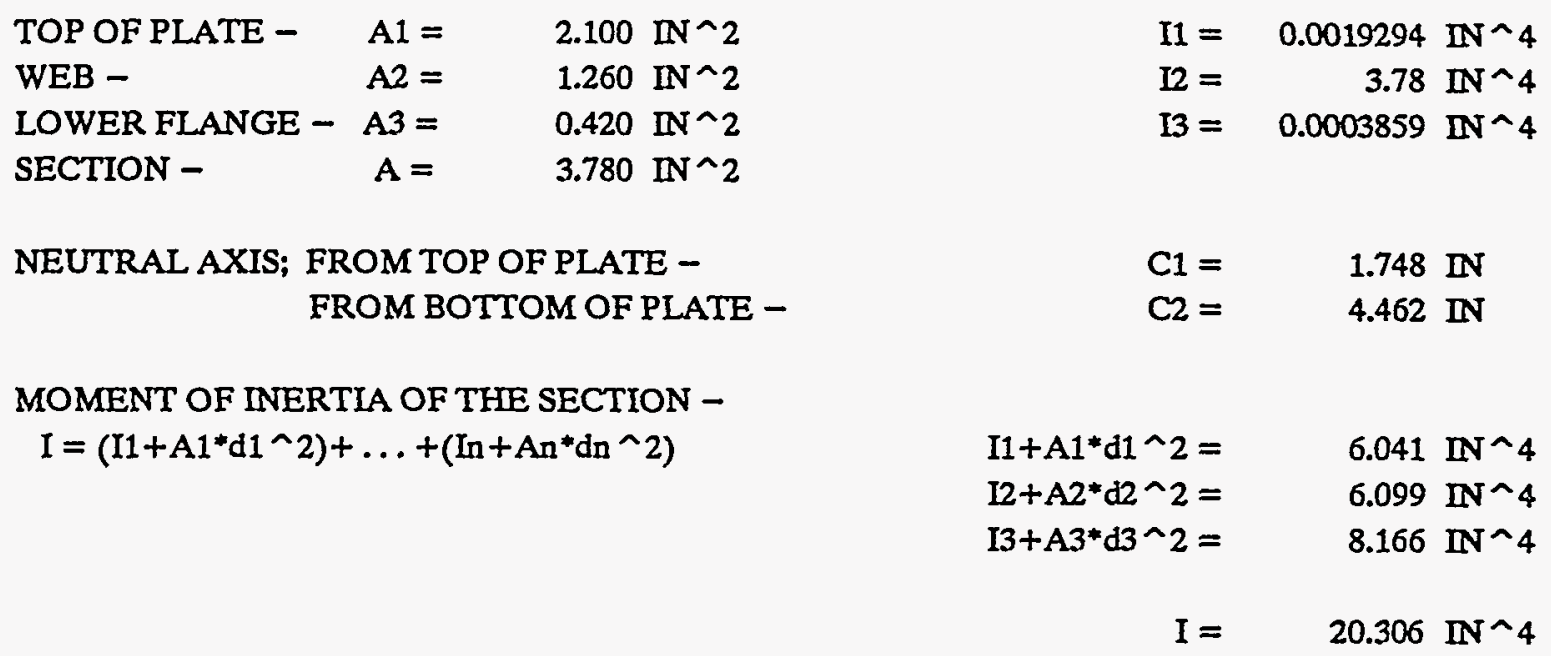

GRID LOADING - $\quad w=\quad 175$ LB/FT

MAXIMUM BENDING MOMENT $-\mathrm{Mmax}=w^{*} \mathrm{~L} \uparrow 2 / 8$

MAXIMUM SHEAR LOAD $-V \max =w^{*} L / 2$

$=\quad 1618 \mathrm{FT}-\mathrm{LB}$

BENDING STRESS, TOP OF SECTION $-\mathrm{Sb}=\mathrm{Mmax} * \mathrm{C} 1 / \mathrm{I}$

$=\quad 188 \mathrm{LB}$

BENDING STRESS, BOTTOM OF SECTION $-\mathrm{Sb}=\mathrm{Mmax}{ }^{*} \mathrm{C} 2 / \mathrm{I}$

$=\quad 1672$ PSI

MAXIMUM SHEAR STRESS - Ss $=$ Vmax/Aw

$=\quad 4266$ PSI

MAXIMUM DEFLECTION - ymax $=5^{*} w^{*} L^{\wedge} 4 /\left(384^{*} E^{*} I\right)$

$=149$ PSI

$=\quad 0.041 \mathrm{IN}$

DISTRIBUTOR GRID PLATE WEIGHT

$=\quad 12296 \mathrm{LB}$

TOTAL WEIGHT OF INTERNAL STUCTURE

$=\quad 38595 \mathrm{LB}$ 